\title{
Bioindication and modelling of atmospheric deposition in forests enable exposure and effect monitoring at high spatial density across scales
}

\author{
Winfried Schröder ${ }^{1} \cdot$ Stefan Nickel $^{1} \cdot$ Simon Schönrock $^{1} \cdot$ Roman Schmalfuß $^{1} \cdot$ Werner Wosniok $^{2}$ • \\ Michaela Meyer $^{1}$ - Harry Harmens ${ }^{3}$ - Marina V. Frontasyeva ${ }^{4}$. Renate Alber ${ }^{5}$ • Julia Aleksiayenak ${ }^{6}$. \\ Lambe Barandovski $^{7}$ - Oleg Blum ${ }^{8}$. Alejo Carballeira ${ }^{9}$ - Maria Dam ${ }^{10}$ - Helena Danielsson ${ }^{11}$. \\ Ludwig De Temmermann ${ }^{12}$ - Anatoly M. Dunaev ${ }^{13}$ - Barbara Godzik ${ }^{14}$ - Katrin Hoydal ${ }^{10}$. \\ Zvonka Jeran ${ }^{15}$ • Gunilla Pihl Karlsson ${ }^{11}$ • Pranvera Lazo ${ }^{16}$ • Sebastien Leblond ${ }^{17}$ • Jussi Lindroos ${ }^{18}$ • \\ Siiri Liiv ${ }^{19}$ • Sigurður H. Magnússon ${ }^{20}$ • Blanka Mankovska ${ }^{21}$ • Encarnación Núñez-Olivera ${ }^{22}$. \\ Juha Piispanen $^{23}$ • Jarmo Poikolainen ${ }^{23}$ • Ion V. Popescu ${ }^{24}$ • Flora Qarri ${ }^{25}$ • Jesus Miguel Santamaria ${ }^{26}$. \\ Mitja Skudnik $^{27} \cdot$ Zdravko Špirić $^{28}$ - Trajce Stafilov ${ }^{7}$ Eiliv Steinnes ${ }^{29} \cdot$ Claudia Stihi $^{24} \cdot$ Ivan Suchara $^{30}$. \\ Lotti Thöni $^{31}$ • Hilde Thelle Uggerud ${ }^{32}$ - Harald G. Zechmeister ${ }^{33}$
}

Received: 22 August 2016 / Accepted: 2 February 2017 /Published online: 10 April 2017

(C) INRA and Springer-Verlag France 2017

\begin{abstract}
- Key message Moss surveys provide spatially dense data on environmental concentrations of heavy metals and nitrogen which, together with other biomonitoring and modelling data, can be used for indicating deposition to terrestrial ecosystems and related effects across time and areas of different spatial extension.
\end{abstract}

Handling Editor: Erwin Dreyer

Contribution of the co-authors The authors designed the investigation, sampled and analysed the moss specimen, and read and approved the manuscript. Winfried Schröder headed the investigation and drafted the manuscript. Michaela Meyer, Stefan Nickel, Roman Schmalfuß and Simon Schönrock computed the statistics. Werner Wosniok contributed to the design of the statistical exercises.

Electronic supplementary material The online version of this article (doi:10.1007/s13595-017-0621-6) contains supplementary material, which is available to authorized users.

Winfried Schröder

winfried.schroeder@uni-vechta.de

Werner Wosniok

wwosniok@math.uni-bremen.de

Harry Harmens

hh@ceh.ac.uk

Marina V. Frontasyeva

mfrontasyeva@jinr.ru
- Context For enhancing the spatial resolution of measuring and mapping atmospheric deposition by technical devices and by modelling, moss is used complementarily as bio-monitor. - Aims This paper investigated whether nitrogen and heavy metal concentrations derived by biomonitoring of atmospheric deposition are statistically meaningful in terms of compliance with minimum sample size across several spatial levels (objective 1), whether this is also true in terms of geostatistical criteria such as spatial auto-correlation and, by this, estimated values for unsampled locations (objective 2) and whether moss indicates atmospheric deposition in a similar way as modelled deposition, tree foliage and natural surface soil at the European and country level, and whether they indicate site-specific variance due to canopy drip (objective 3 ).

- Methods Data from modelling and biomonitoring atmospheric deposition were statistically analysed by means of minimum sample size calculation, by geostatistics as well as by bivariate correlation analyses and by multivariate correla-

\footnotetext{
Renate Alber renate.Alber@provinz.bz.it

Julia Aleksiayenak beataa@gmail.com

Lambe Barandovski lambe@pmf.ukim.mk

Oleg Blum

blum@nbg.kiev.ua
} 
tion analyses using the Classification and Regression Tree approach and the Random Forests method.

- Results It was found that the compliance of measurements with the minimum sample size varies by spatial scale and element measured. For unsampled locations, estimation could be derived. Statistically significant correlations between concentrations of heavy metals and nitrogen in moss and modelled atmospheric deposition, and concentrations in leaves, needles and soil were found. Significant influence of canopy drip on nitrogen concentration in moss was proven.

- Conclusion Moss surveys should complement modelled atmospheric deposition data as well as other biomonitoring approaches and offer a great potential for various terrestrial monitoring programmes dealing with exposure and effects.

Mitja Skudnik

mitja.skudnik@gozdis.si

Zdravko Špirić

zdravko_spiric@hotmail.com

Trajce Stafilov

trajcest@pmf.ukim.mk

Eiliv Steinnes

eiliv.steinnes@chem.ntnu.no

Claudia Stihi

stihi@valahia.ro

Ivan Suchara

suchara@vukoz.cz

Lotti Thöni

lotti.thoeni@fub-ag.ch

Hilde Thelle Uggerud

hilde.thelle.uggerud@nilu.no

Harald G. Zechmeister

harald.zechmeister@univie.ac.at

Pranvera Lazo

pranveralazo@gmail.com

Sebastien Leblond

sleblond@mnhn.fr

Jussi Lindroos

antti.lindroos@luke.fi

Siiri Liiv

siiri.liiv@botaanikaaed.ee

Sigurður H. Magnússon

sigurdur@ni.is

Blanka Mankovska

bmankov@stonline.sk

Encarnación Núñez-Olivera

encarnacion.nunez@unirioja.es

Juha Piispanen

juha.piispanen@luke.fi

Jarmo Poikolainen

jarmo.poikolainen@gmail.com

Ion V. Popescu

ivpopes@yahoo.com

Flora Qarri

flora.qarri@gmail.com

Jesus Miguel Santamaria

chusmi@unav.es

4 Moss Survey Coordination Centre, Frank Laboratory of Neutron Physics, Joint Institute for Nuclear Research, Dubna, Moscow Region, Moscow, Russia

5 Environmental Agency of Bolzano, Laives, Italy

6 International Sakharov Environmental University, Minsk, Belarus

7 Ss. Cyril and Methodius University, Skopje, Macedonia

8 National Botanical Garden, Academy of Science of Ukraine, Kiev, Ukraine

9 Ecologia Facultad De Biologia, University of Santiago de Compostela, Santiago de Compostela, Spain

10 Environment Agency, Argir, Faroe Island

11 IVL Swedish Environmental Research Institute, Göteborg, Sweden

12 Veterinary and Agrochemical Research Centre CODA-CERVA, Tervuren, Belgium

13 Ivanovo State University of Chemistry and Technology, Ivanovo, Russia

14 W. Szafer Institute of Botany, Polish Academy of Sciences, Kraków, Poland 
Keywords Bioaccumulation - Biomonitoring - EMEP . Environmental specimen bank · ICP Forests Level II · LOTOS-EUROS

\section{Introduction}

Forests filter substances such as heavy metals (HM) and nitrogen $(\mathrm{N})$ from the atmosphere and are thus exposed particularly to atmospheric deposition influencing their condition (Bjerregaard et al. 2015; Michel et al. 2014; Michel and Seidling 2015; Tchounwou et al. 2012, 2014). HM like lead $(\mathrm{Pb})$ and mercury $(\mathrm{Hg})$ are persistent, toxic and/or bioaccumulative and can positively correlate with trophic levels of organisms (biomagnification) (Bjerregaard et al. 2015; Murray 2005). Deposition affects forest ecosystems through exceeding effect-based critical levels of single species and through exceeding critical loads of whole ecosystems (ARGE StickstoffBW 2014; de Vries and Groenenberg 2009; Giordani et al. 2014; Lorenz et al. 2008). Protecting the integrity of forest ecosystems and their specific functional importance to the atmosphere, hydrosphere and biodiversity requires deposition monitoring data at a high spatial resolution for the International Cooperative Programme on Modelling

\footnotetext{
15 Jožef Stefan Institute, Ljubljana, Slovenia

16 University of Tirana, Tirana, Albania

17 National Museum of Natural History, Paris, France

18 Natural Resources Institute, Helsinki, Finland

19 Tallinn Botanic Garden, Tallinn, Estonia

20 Icelandic Institute of Natural History, Garðabær, Iceland

21 Institute of Landscape Ecology, Slovak Academy of Sciences, Bratislava, Slovakia

22 Universidad de La Rioja, Logroño, Spain

23 Natural Resources Institute Finland (Luke), Oulou, Finland

24 Valahia University of Targoviste, Targoviste, Romania

25 University of Vlora, Vlorë, Albania

26 University of Navarra, Navarra, Spain

27 Slovenian Forestry Institute, Ljubljana, Slovenia

28 Green Infrastructure Ltd, Zagreb, Croatia

29 Norwegian University of Science and Technology, Trondheim, Norway

30 Silva Tarouca Research Institute for Landscape and Ornamental Gardening, Průhonice, Czech Republic

31 FUB-Research Group for Environmental Monitoring, Rapperswil, Switzerland

32 Norwegian Institute for Air Research, Kjeller, Norway

33 University of Vienna, Wien, Austria
}

and Mapping of Critical Levels and Loads and Air Pollution Effects, Risks and Trends (ICP Modelling and Mapping).

The European Monitoring and Evaluation Programme (EMEP) indicated a twofold decrease of cadmium (Cd) atmospheric concentrations and deposition between 1990 and 2003, with 10-80\% of deposition in Europe derived from European emissions (Nordberg et al. 2014; Steinnes 1989; UNECE TF HM, Task Force on Heavy Metals 2006; UNEP 2010a). EMEP monitoring and modelling in Europe corroborated a general two- to threefold decrease in atmospheric concentrations and deposition of $\mathrm{Pb}$ between 1990 and 2003, with transboundary transport across Europe accounting for 10-90\% of deposition in European countries. Results from the International Cooperative Programme on Integrated Monitoring of Air Pollution Effects on Ecosystems (ICP Integrated Monitoring) revealed that $\mathrm{Pb}$ deposition was accumulated in forested catchments of Northern and Central Europe (UNECE TF HM, Task Force on Heavy Metals 2006; UNEP 2010 b). Also, other metals such as arsenic (As), chromium $(\mathrm{Cr})$, copper $(\mathrm{Cu})$, nickel $(\mathrm{Ni})$, zinc $(\mathrm{Zn})$, and antimony $(\mathrm{Sb})$ have the potential for long-range atmospheric transport and accumulate in environments far from emission sources (Bjerregaard et al. 2015; UNECE TF HM, Task Force on Heavy Metals 2006).

From 1880 to 2005 , total $\mathrm{N}$ emission has increased by $540 \%$ (de Vries et al. 2014). N deposition data collected during the year 2011 at 219 Level II plots of the International Cooperative Programme on Assessment and Monitoring of Air Pollution Effects on Forests (ICP Forests Level II) in 24 countries across Europe indicated high deposition levels in Central Europe, Denmark and Switzerland ( Berg and Dise 2004; Seidling et al. 2014).

As a consequence of potential effects of atmospheric deposition of air pollutants such as $\mathrm{HM}$ and $\mathrm{N}$ in forest ecosystems, a Pan-European Programme for Intensive and Continuous Monitoring of Forest Ecosystems (ICP Forests Level II) started in 1994. Currently, it comprises approximately 760 permanent plots in 30 participating countries, including 500 plots with atmospheric deposition and forest ecosystem impact monitoring (de Vries et al. 2014). Comparability and meaningful interpretation of data derived from long-term monitoring across time require representative measurements based on harmonized methods and a statistically sound design (Clarke et al. 2010; Cools and de Vos 2011; Ferretti 2010, 2011; Ferretti et al. 2014, Fischer et al. 2014). Within this context, the spatial representativity and comparability of atmospheric deposition measurements are crucial issues - for exposure and effect assessments (Bleeker et al. 2003; Erisman et al. 2003; Lorenz and Granke 2009; Žlindra et al. 2011). Clarke et al. (2010) found large differences in results of different types of technical samplers and that several factors might influence the measurements, among them the number and surface area of samplers used as well as their placing in the stands and the extent of the area equipped with collectors. The 
differences in the results obtained impede using the deposition data for model evaluation. Variation due to the samplers exceeded those from chemical analyses conducted in different laboratories. Even if the moss technique is widely accepted as a biological monitor for the accumulation of atmospheric deposition and, as such, surrogate tool for mapping deposition (de Vries et al. 2014; Harmens et al. 2015a, 2015b, 2015c; Seidling et al. 2014; Stankovic et al. 2014), but approved only in parts by Fernández et al. (2015a, 2015b), compilations of relevant forest monitoring programmes (Clarke et al. 2011; Fischer et al. 2011; Lorenz and Granke 2009) do not include the results from the European Moss Survey (EMS). This gives reason to have a closer look at the data from the EMS and to investigate whether they could be useful for other environmental programmes such as ICP Forests. Therefore, this paper aims at introducing the methodology and exemplary results of moss surveys and at sketching the potential of the data for application in terrestrial monitoring. Since terrestrial monitoring relies on spatial point data, the spatial representativity in terms of minimum sample size (MSS) and spatial autocorrelation are of fundamental significance (Clarke et al. 2011; Ferretti 2010, 2011; Ferretti and Fischer 2013; Rüdel et al. 2009; Sachs and Hedderich 2009). To this end, data from moss surveys were investigated whether they are statistically meaningful in terms of compliance with minimum sample size computed for both, Ecological Land Classes of Europe, describing the spatial patterns of 40 to 230 natural landscapes by characteristic values of 48 ecological attributes (Hornsmann et al. 2008; Schröder and Pesch 2007), and for sampling sites in north-western Germany (1), and in terms of geostatistical criteria such as spatial auto-correlation which could enable estimating values for unsampled locations and computing surface maps (2). Additionally, the study investigated whether moss specimens indicate atmospheric deposition in a similar way as modelled deposition, tree foliage and natural surface soil at the European and country level, and whether they indicate site-specific variance due to canopy drip (3). Since the results of modelling of deposition may depend on the structure and functions of the models as well as on the input data in terms of meteorology and emissions (Dore et al. 2015; Ilyin and Travnikov 2005), we used results from the EMEP and LOTOS-EUROS deposition model. These three objectives were examined with the data and methods compiled in Table 1 and explained in Section 2 sub-divided into "Data" (Section 2.1), "Minimum sample size" (Section 2.2), "Geostatistics and mapping" (Section 2.3) and "Correlation analyses" (Section 2.4).

In a first step, EMS measurements were investigated by calculating and mapping the minimum sample size (MSS) for ecologically defined land classes across Europe. The spatial validity of the data was examined additionally by means of geostatistics. Then, to specify the indicative significance of the biomonitors moss (EMS), leaves, needles (German Environmental Specimen Bank-ESB, ICP Forests Level II) and surface soil specimens (ICP Forests Level II) for atmospheric deposition modelled by EMEP and LE, correlation analyses were conducted.

\section{Material and methods}

\subsection{Data}

To establish interrelationships between indicanda (here: atmospheric deposition) and indicators (here: moss, tree foliage, soil) (Gao et al. 2015), i.e. to determine the indicative validity of moss

Table 1 Objectives, data and methods (specified in Table S1)

\begin{tabular}{|c|c|c|}
\hline Objectives & For more detailed descriptions, see Table 2 & Methods \\
\hline $\begin{array}{l}\text { Determination of minimum sample } \\
\text { size (MSS) }\end{array}$ & $\begin{array}{l}\text { Element concentrations in moss: EMS } 2010 \\
\text { (Harmens et al. 2015b) }\end{array}$ & $\begin{array}{l}\text { MSS approach (Schröder et al. } 2016 \text { and complemented } \\
\text { by this investigation) }\end{array}$ \\
\hline $\begin{array}{l}\text { Mapping geographic patterns of element } \\
\text { concentration across Europe }\end{array}$ & $\begin{array}{l}\text { Element concentrations in moss: EMS } 2010 \\
\text { (Harmens et al. 2015b) }\end{array}$ & $\begin{array}{l}\text { Variogram analysis of spatial auto-correlation } \\
\text { Kriging interpolation: surface estimation of element } \\
\text { concentrations for unsampled areas }\end{array}$ \\
\hline $\begin{array}{l}\text { Indicative validity of bioindicators } \\
\text { for atmospheric deposition including } \\
\text { canopy drip effects }\end{array}$ & $\begin{array}{l}\text { Element concentrations in moss: German } \\
\text { and European Moss Survey 2005-GMS } \\
2005 \text { (Pesch et al. 2007) } \\
\text { Element concentrations in tree foliage: } \\
\text { German Environmental Specimen Bank } \\
\text { ESB 2005-2011 (Rüdel et al. 2009) } \\
\text { Element concentrations in tree foliage and } \\
\text { soil: German ICP Forests Level II sites } \\
\text { 2005-2011 (Ferretti and Fischer 2013) } \\
\text { Atmospheric deposition 2005-2011 } \\
\text { modelled by EMEP and LOTOS-EUROS } \\
\text { (Nickel and Schröder 2016) }\end{array}$ & $\begin{array}{l}\text { Correlation analyses } \\
\text { Spearman rank correlation }\left(r_{\mathrm{S}}\right) \text { between deposition and } \\
\text { moss data } \\
\text { Kendall rank correlation }\left(r_{\tau}\right) \text { between deposition data and } \\
\text { tree foliage and soil data } \\
\text { Classification and Regression Trees (CART) } \\
\text { Random Forest }(\mathrm{rF})\end{array}$ \\
\hline
\end{tabular}

${ }^{\mathrm{a}}$ The German Moss Survey (GMS) is part of the European Moss Survey (EMS) 
and other biomonitors (Lindenmayer and Likens 2011; Lindenmayer et al. 2015), correlation analyses were performed. To this end, data on HM concentrations in leaves, needles and soil collected for the ESB in 4 ecosystem types at 13 sites across Germany and from 90 German ICP Forests Level II plots as well as Europe- and Germany-wide modelled atmospheric deposition data were used (Tables 1 and 2). Data on foliar chemistry sampled at roughly 1900 sites of the nationwide soil monitoring (Hilbrig et al. 2014) could not be made available. From ESB, $\mathrm{HM}$ concentrations in leaves and needles collected during 2005 and 2007-2011 in representative terrestrial ecosystems (agricultural, urban-industrial, forestry and nearly natural) were acquired. These data comprise annual leaves collected from beech (Fagus sylvatica L.) and poplar (Populus nigra 'Italica' L.) and 1-year old shoots from spruce (Picea abies L.) and pine (Pinus sylvestris L.). All samples were analysed annually for As, $\mathrm{Cd}$, cobalt ( $\mathrm{Co}$ ), $\mathrm{Cr}, \mathrm{Cu}, \mathrm{Hg}$, molybdenum (Mo), $\mathrm{Ni}$, $\mathrm{Pb}$, titanium (Ti) and $\mathrm{Zn}$ concentrations according to standardized guidelines for sampling and sample treatment (UBA 2008). Concentrations of $\mathrm{Cd}, \mathrm{Cu}, \mathrm{Mn}, \mathrm{Pb}$ and $\mathrm{Zn}$ in needles and leaves collected between 2000 and 2012 on ICP Forests Level II sites were added (Rautio et al. 2010).

Furthermore, data on atmospheric deposition modelled within the framework of EMEP (Tørseth et al. 2012) and calculated with LOTOS-EUROS (Builtjes et al. 2014) were integrated. The EMEP model provides data on Europe-wide data on total atmospheric deposition of $\mathrm{Pb}, \mathrm{Cd}$ and $\mathrm{Hg}\left(\mu \mathrm{g} \mathrm{m}^{-2}\right.$ year $\left.^{-1}\right)$ on a grid of $50 \mathrm{~km}$ by $50 \mathrm{~km}$ calculated by use of emission and meteorological data. In this study, data for the total atmospheric deposition of $\mathrm{Cd}$ and $\mathrm{Pb}(2005,2007-2011)$ and land usespecific data on atmospheric deposition of $\mathrm{Cd}$ and $\mathrm{Pb}$ (2011) for 3 of 18 classes comparable with those from LE were used: grassland as well as deciduous and coniferous forests. The EMEP grid consists of 204 cells across Germany. For each EMEP raster grid, the median and other descriptive statistical measures from the respective LE grids were calculated. Using emission data and meteorological data, LE produces total deposition values $\left(\mu \mathrm{g} \mathrm{m}^{2}\right.$ year $\left.^{-1}\right)$ for $\mathrm{As}, \mathrm{Cr}, \mathrm{Cu}, \mathrm{Ni}$, vanadium $(\mathrm{V})$ and $\mathrm{Zn}$ for 2009-2011 and, respectively, $\mathrm{Cd}$ and $\mathrm{Pb}$ for 2005 with a spatial resolution of $25 \mathrm{~km}$ by $25 \mathrm{~km}$ for Europe and deposition data for $\mathrm{Cd}$ and $\mathrm{Pb}(2007-2011)$ on a grid of $7 \mathrm{~km}$ by $7 \mathrm{~km}$ covering Germany ( 9 land use classes, averaged over the land use classes in each grid cell). The modelled deposition values rely on meteorological data 2009-2011 (Europe) and 2007-2011 (Germany) respectively and emission data for 2000 (As, Cr, Cu, Ni, V, Zn) and 2005 (Cd, Pb) so that they do not contain any emission trend, contrary to the EMEP modelling results (Nickel and Schröder 2016).

$\mathrm{HM}$ and $\mathrm{N}$ concentrations in moss specimens were derived from the EMS which since 1990 has been providing data on concentrations of up to 40 metallic elements in moss, concentrations of nitrogen since 2005 and persistent organic pollutants since 2010 every 5 years. In Germany, during 19902005 , moss was sampled at roughly $700-1000$ sites. All over Europe, up to 7300 sites were sampled (Harmens et al. 2015a). The EMS provides data on $\mathrm{HM}$ and $\mathrm{N}$ concentrations in naturally growing moss following a harmonized methodology (ICP Vegetation 2014; Špirić et al. 2014; Vučković et al.

Table 2 Characteristics of variogram models for Europe-wide HM and N concentrations in moss (2010)

\begin{tabular}{|c|c|c|c|c|}
\hline & $\mathrm{Cd}$ & $\mathrm{Hg}$ & $\mathrm{Pb}$ & $\mathrm{N}$ \\
\hline \multicolumn{5}{|l|}{ Model settings } \\
\hline Method & Universal kriging & Universal kriging & Ordinary kriging & Universal kriging \\
\hline Transformation & Lognormal & Lognormal & - & Lognormal \\
\hline Trend removal & 2nd-order polynom & 2nd-order polynom & - & 2nd-order polynom \\
\hline Variogram model & Gaussian & Spherical & Spherical & Exponential \\
\hline Lag size $(m)$ & 33.000 & 19.000 & 27.000 & 21.000 \\
\hline Lag number & 10 & 11 & 9 & 12 \\
\hline Search radius & 4 sectors & 4 sectors & 4 sectors & 4 sectors \\
\hline Max. number of neighbours included & 10 & 10 & 10 & 10 \\
\hline \multicolumn{5}{|l|}{ Model parameter and validation } \\
\hline Sample number & 4.006 & 3.514 & 3.836 & 2.411 \\
\hline Nearest neighbour distance (km) & 17.6 & 18 & 17.8 & 18.1 \\
\hline Range (m) & 330.000 & 209.000 & 226.094 & 252.000 \\
\hline Nugget & 0.24 & 0.09 & 0.17 & 0.04 \\
\hline Sill & 0.35 & 0.17 & 0.31 & 0.06 \\
\hline Nugget-sill ratio & 0.68 & 0.54 & 0.55 & 0.62 \\
\hline Mean error (ME) & -0.007 & -0.0008 & -0.30 & 0.0004 \\
\hline Median percental error (MPE) & 28.1 & 20.1 & 25.7 & 14.0 \\
\hline
\end{tabular}


2013) enabling to map spatial patterns and temporal trends of $\mathrm{HM}$ and $\mathrm{N}$ concentrations in moss.

According to the European guideline (ICP Vegetation 2014), in 2005, moss specimens were collected at 726 sample sites across Germany. Further data derived from moss specimen collected at 41 plots in the year 2004 in two regions in north-west and middle east Germany (Schröder et al. 2007) were added. The canopy drip effect on concentrations of $\mathrm{Cd}$, $\mathrm{Cr}, \mathrm{Cu}, \mathrm{Hg}, \mathrm{N}, \mathrm{Ni}, \mathrm{Pb}$ and $\mathrm{Zn}$ in moss was determined in specimens sampled in north-western Germany. Thereby, samplings were conducted beyond forest tree canopies (open site, $n=26$ in 2012 and 2013), below forest tree canopies (throughfall site, $n=30$ in 2012 and 2013) and at the border between these two site categories (edge site, $n=24$ in 2012, $n=23$ in 2013) (Meyer 2017; Meyer et al. 2015a). Measured concentrations $\left(\mu \mathrm{g} \mathrm{g}^{-1}\right.$ ) of $\mathrm{As}, \mathrm{Cd}, \mathrm{Co}, \mathrm{Cr}, \mathrm{Cu}, \mathrm{Hg}, \mathrm{Mn}, \mathrm{Mo}$, $\mathrm{Ni}, \mathrm{Pb}, \mathrm{Sb}, \mathrm{Ti}, \mathrm{V}$ and $\mathrm{Zn}$ in moss collected at 767 sites across Germany in 2005 and geostatistical maps on $\mathrm{Cd}$ and $\mathrm{Pb}$ concentrations $\left(\mu \mathrm{g} \mathrm{g}^{-1}\right)$ in moss sampled across Germany in 2005 in a spatial resolution of $3 \mathrm{~km}$ by $3 \mathrm{~km}$ were derived from Pesch et al. (2007) and Schröder et al. (2007).

\subsection{Minimum sample size}

To calculate the minimum sample size (MSS) needed to estimate statistical mean values within a tolerance of $20 \%$, several formulas exist. Basically, their application depends on certain characteristics of the data used, as for instance the statistical distribution. Accordingly, for data following a normal distribution and for data with a lognormal distribution, several computations were performed to calculate the MSS for concentrations of $\mathrm{Al}, \mathrm{As}, \mathrm{Cd}, \mathrm{Cr}, \mathrm{Cu}, \mathrm{Fe}, \mathrm{Hg}, \mathrm{N}, \mathrm{Ni}, \mathrm{Pb}, \mathrm{S}, \mathrm{Sb}, \mathrm{V}$ and $\mathrm{Zn}$ in moss sampled across Europe in 2010 (Nickel and Schröder 2016). Thereby, the following spatial levels were regarded: the ecological land classes covering Europe and the sample sites in north-western Germany dedicated to the investigation of canopy drip effects. The minimum sample size calculations were based on data collected in the framework of EMS 2010 and of the regional study in 2012 and 2013. The first exercise was accomplished by overlaying the EMS sample network map with the map of the Ecological Land Classification of Europe (ELCE) (Hornsmann et al. 2008; Schröder and Pesch 2007). Following Land (1971) and Olsson (2005) for each of the $\mathrm{ELCE}_{40}$ classes, i.e. the lowest level of specification, the MSS were calculated according to formulas detailed by Schröder et al. $(2014,2016)$ and mapped.

\subsection{Geostatistics and mapping}

Terrestrial monitoring approaches do not reach a complete coverage but rely on spatial samples. The aim of spatial modelling is constructing models to predict spatial patterns from measurements, i.e. to fill up the space between the measurement sites by spatial estimation. Whether this is possible or not can be examined applying variogram analysis. By this, the relation between measurement variance and spatial distance between sites of sampling and observation, respectively, i.e. the spatial auto-correlation can be modelled by use of kriging techniques. The respective function derived from the sample data can then be used to interpolate between the sites with measurements. For the correlation analyses, not only the moss measurement values (2005) were used but also surface estimation for the year 2005 derived by kriging (Pesch et al. 2007).

For regionalizations at the European level, data from EMS 2010 on $\mathrm{Cd}, \mathrm{Hg}, \mathrm{Pb}$ and $\mathrm{N}$ concentrations from 2411 (N) up to 4006 (Cd) moss samplings were taken. Geostatistical analyses have been carried out by means of ESRI's ArcGIS 10.2. Trend analyses were performed in order to identify element-specific spatial trends in the datasets. In cases where spatial trends were detected, universal kriging was used with trend removal, while, vice versa, ordinary kriging was performed where the assumption of a constant global mean was reasonable.

Meaningful parameters for determining the spatial autocorrelation and evaluating the semi-variogram are the socalled nugget, sill and major range. A low nugget-sill ratio indicates a positive auto-correlation within the major range which enables the calculation of comprehensive maps of element concentration in moss by use of kriging interpolation. Accuracy of variogram models were quantified as mean error (ME). Cross validation was performed for evaluating the kriging maps by use of the median percental error (MPE) as the difference between measured and estimated values in percent.

\subsection{Correlation analyses}

Spearman rank correlation $\left(r_{\mathrm{S}}\right)$ between deposition and moss data and Kendall rank correlation $\left(r_{\tau}\right)$ between deposition data and tree foliage and soil specimen were calculated. These measures are useful for small sample sizes $\left(r_{\tau}\right)$ and variables with different spacings. They are robust in the presence of outliers and require neither normal distribution nor linearity of relations, i.e. it is applicable also for logarithmic or exponential relations (Hennemuth et al. 2013). $r_{\mathrm{S}}$ and $r_{\tau}$ are between -1 and $+1 . r_{\tau}$ values usually are somewhat lower than $r_{\mathrm{S}}$ and Pearson's correlation measures. The significance of differences between medians of HM deposition values was examined by application of the Wilcoxon signed-rank test, and the significance of differences between correlation coefficients was calculated according to Sachs and Hedderich (2009) as detailed by Nickel and Schröder (2016). The correlation analyses encompassed (Tables 1 and 2) the following: (a) EMEP and LE modelled HM deposition values; (b) EMEP and LE modelled HM deposition values and respective HM concentrations measured in moss 2005 
and spatially estimated for unsampled locations; (c) EMEP and LE modelled HM deposition values and respective HM concentrations in tree foliage (ESB and ICP Forests) and surface soil specimens (ICP Forests); (d) concentrations of $\mathrm{Cd}$, $\mathrm{Cr}, \mathrm{Cu}, \mathrm{Hg}, \mathrm{N}, \mathrm{Ni}, \mathrm{Pb}$ and $\mathrm{Zn}$ in moss collected inside and outside of forests in north-western Germany. For the latter investigation, computations of bivariate correlation between concentrations of $\mathrm{HM}$ and $\mathrm{N}$ in moss and site factors were complemented by multivariate analyses conducted by the Classification and Regression Tree (CART) method and the Random Forest approach (rF) (Meyer 2017; Meyer et al. 2015a). Potentially influencing factors regarded were the following: site category (open, edge, throughfall); modelled atmospheric deposition $(\mathrm{Cd}, \mathrm{Hg}, \mathrm{N}, \mathrm{Pb})$; distance between sampling sites and roads, residential areas, distance to sea, EPRTR $^{1}$ sources; land use (agricultural, silvicultural, urban) in different radiuses around sampling sites; buildings for livestock; industry; altitude above sea level; annual average precipitation; and population density.

$\mathrm{rF}$ models are used to construct a prediction rule and to assess and rank variables with respect to their ability to predict the response variable. If the $\mathrm{rF}$ minimizes a squared error, normal distribution is not an essential requirement. But extremely asymmetric error distributions reduce the quality of predictions and make e.g. the difference between mean and median prediction important. The ranking is done by considering variable importance measures computed for each predictor. These relative measures as pure numbers without unit identify and rank predictors. After validation, the resulting prediction rule can then be applied, e.g. for mapping element concentrations in environmental compartments such as soil or moss. $\mathrm{rF}$ can cope with high dimensional data and can even be applied to highly correlated predictors, is not based on a particular stochastic model and can also capture nonlinear association patterns between predictors and the response. $\mathrm{rF}$ is a classification and regression technique aggregating a large number of decision trees. Several trees constructed from a training data set yield a prediction of the response. Variants of $\mathrm{rF}$ are characterized by the procedure used to generate the modified data sets on which each individual tree is constructed, and by the way the predictions of each individual tree are aggregated to produce a unique consensus prediction. In the original $\mathrm{rF}$ method (Breiman 2001), each tree is a standard classification or regression tree (CART) (Breiman et al. 1984) using the decrease of Gini impurity, i.e. the degree of heterogeneity of a variable measured by the Gini index as a

\footnotetext{
${ }^{1}$ European Pollutant Release and Transfer Register: Europe-wide register providing environmental data from industrial facilities in European Union Member States and in Iceland, Liechtenstein, Norway, Serbia and Switzerland. The register contains data reported annually by more than 30,000 industrial facilities covering 65 economic activities, among them amounts of pollutant releases to air and water. Information is provided on 91 key pollutants including heavy metals for year 2007 onwards.
}

splitting criterion and selecting the splitting predictor from a randomly selected subset of predictors. Each tree is constructed using a bootstrap sample from the original data set, and the predictions of all trees are finally aggregated. This version of $\mathrm{rF}$ is implemented in most of the available software. Internal validation is calculated in terms of the out-of-bag $(\mathrm{OOB})$ error: Each observation is an $\mathrm{OOB}$ observation for some of the trees, i.e. it was not used to construct them. The OOB error is the average error frequency obtained when the observations from the data set are predicted using the trees for which they are OOB. Thus, $\mathrm{rF}$ are ensembles of multiple decision trees combined into a single model. Compared with single-decision trees, like CART, $\mathrm{rF}$ tends to be more robust to outliers and overfitting (Williams 2011; Ziegler and König 2014). Verikas et al. (2011) surveyed respective literature and presented comparatively several tests. CART models are prone to overfitting data, which can lead to predictive errors. $\mathrm{rF}$ models reduce the over-fitting problem. Instead of building a single predictive tree model from all available data, RF builds typically 500 to 2000 trees (Prasad et al. 2006), using randomized subsets of data and explanatory variables to build each tree. The number of predictors used to find the best split at each node is a randomly chosen subset of the total number of predictors. The $\mathrm{rF}$ trees are grown to maximum size without pruning, and aggregation is performed by averaging the trees. Out-of-bag samples can be used to calculate an unbiased error rate and variable importance. Because a large number of trees are grown, there is limited generalization error (i.e. the true error of the population opposed to the training error only). The impossibility of overfitting is a very useful feature for prediction. By growing each tree to maximum size without pruning and selecting only the best split among a random subset at each node, $\mathrm{rF}$ tries to maintain some prediction strength while inducing diversity among trees (Breiman 2001). Random predictor selection diminishes correlation among unpruned trees and keeps the bias low. By taking an ensemble of unpruned trees, variance is also reduced. Another advantage of $r F$ is that the predicted output depends only on one user-selected parameter, with the number of predictors to be chosen randomly at each node. This process of internal cross-validation prevents from over-fitting inherent to a single CART model (Breiman 2001).

\section{Results}

\subsection{Minimum sample size}

Selected results from MSS calculation and mapping are given in Figs. 1, 2, 3, 4 and S2-S11). Respective results for EMS 2005 were already presented by example of N (Schröder et al. 2014). 
Fig. 1 Compliance of minimum sample size for $\mathrm{Cd}$ concentrations in moss (2010) at the landscape level as determined by use of the Ecological Land Classification of Europe $\mathrm{ELCE}_{40}$



At the European scale, the realized sample size (RSS) reaches the required minimum sample size (MSS) in all cases of the 14 considered elements. However, on a national scale, only two (N, S) of the 14 considered elements comply with the required sample size in $100 \%$ of the countries in which the respective elements were collected. For all other elements, the MSS is reached in 58\% to $90 \%$ of the participating countries. On the other hand, 6 out of the 25 participating countries, so nearly $24 \%$, reach the MSS for all elements that were collected by the respective country. When considering the $\mathrm{ELCE}_{40}$ units (Figure S1 and Table S1), which in contrast to the administrative areas of the national states are not contiguous areas, some differences compared to the national level were found. Moss sample sites are located in 32 of the 40 ELCE units. However, none of the 14 examined elements reach the MSS in all ELCE units where moss specimens were sampled. The lowest percentage was calculated for Al reaching the MSS in only $34 \%$ of the ELCE units containing sample sites with Al measurements. Taking a look at the particular ELCE units, at least four of the 32 ecoregions containing sampling sites comply with the MSS for all elements measured within the respective ecoregion. On the other hand, in comparison to the national level, three ecoregions with very low percentage of sufficient
MSS per element were found. In one ELCE40 unit all measured elements did not reach the MSS. Concerning the level of compliance of the particular ELCE units for $\mathrm{Cd}, \mathrm{Hg}, \mathrm{Pb}$ and $\mathrm{N}$, three-digit absolute values for MSS were reached within many ecoregions (Schröder et al. 2016), which corresponds with the results on the national scale.

Considering the lowest spatial scale - the $\mathrm{ELCE}_{40}$ units within each participating country - it turned out that none of the elements reaches the MSS in $100 \%$ of the $\mathrm{ELCE}_{40}$ units of the single participating countries (Schröder et al. 2016). A maximum was calculated for $\mathrm{N}$ and $\mathrm{S}$ for which at least $76 \%$ and $80 \%$ of the landscapes within the single countries respectively reach the MSS. However, more than half of the 14 analysed elements do not reach even 50\%. Regarding the ELCE units within the single countries particularly, in $8 \%$ of the cases MSS was reached for all elements sampled within the respective unit of a certain country. In $13 \%$ of the cases the MSS was not reached for all sampled elements. Furthermore, the analysis revealed that indeed some landscapes comply with the MSS regarding the European level. However, when examining the same landscape within a single participating country, this fact is not true anymore in some cases. 
Fig. 2 Compliance of minimum sample size for $\mathrm{Pb}$ concentrations in moss (2010) at the landscape level as determined by use of the Ecological Land Classification of Europe ELCE 40



Figures 1, 2, 3 and 4 show the spatial distribution of RSS and MSS values for $\mathrm{Cd}, \mathrm{Hg}, \mathrm{Pb}$ and $\mathrm{N}$ in ecologically defined European landscapes. For Cd, more than half of the $\mathrm{ELCE}_{40}$ classes $(68 \%)$ were sufficiently sampled in the year 2010 . Other ecological regions which should have been sampled more often for reliable analysis of $\mathrm{Cd}$ are predominantly located in Albania, Bulgaria, Norway and South West France (Fig. 1). Concerning $\mathrm{Pb}$ concentrations in moss $\mathrm{ELCE}_{40}$ units without having attained the minimum number of sample sites amounts to $42 \%$. Core areas of these underrepresented land classes could be found in Albania, Austria, Bulgaria, France, Macedonia, Norway, Slovakia, Slovenia and Switzerland (Fig. 2). For $\mathrm{Hg}$, the moss samplings in $17 \%$ of the $\mathrm{ELCE}_{40}$ units did not allow reliably to determine a mean in the range of $20 \%$ around the true mean. These landscape classes cover in particular parts of Albania, Bulgaria, Croatia, Macedonia and South France (Fig. 3). With regard to N concentration in moss, almost the full spectrum of ELCE 40 units (24 out of 27) were sampled sufficiently. Concerning the minimum number of sample sites, we could determine three land classes, which did not feature enough information for reliable statistics. Areas covered by these units were not widely distributed in
Austria, Finland and Switzerland (Fig. 4). Additional maps for $\mathrm{HM}$ are given in the supplement (Figs. S2-S11).

When sampling inside and outside of forests to detect the canopy effects on concentrations of $\mathrm{N}, \mathrm{Cd}, \mathrm{Cu}, \mathrm{Cr}$, $\mathrm{Hg}, \mathrm{Ni}, \mathrm{Pb}$ and $\mathrm{Zn} 2012$ and 2013 in north-western Germany, in most cases, the minimum sample size could be reached or even exceeded. In case of $\mathrm{Cr}$, the minimum sample size in open fields could not be met: In 2012 (2013), 26 (24) sites were sampled; however, 154 (42) should have been sampled. For Pb, 30 measurements within forest stands could be realized in 2012 instead of 64 (Meyer 2017; Meyer et al. 2015b).

\subsection{Geostatistics and mapping}

The results of geostatistics in terms of variogram analyses and kriging estimation were computed from the EMS 2010 across Europe and can be summarized as follows. As a result of variogram analyses, major ranges for the investigated 4 elements vary between $209 \mathrm{~km}$ $(\mathrm{Hg})$ and $330 \mathrm{~km}(\mathrm{Cd})$ (Table 2). Nugget-sill ratios came out to be between $0.54(\mathrm{Hg})$ and $0.68(\mathrm{Cd})$. Respective 
Fig. 3 Compliance of minimum sample size for $\mathrm{Hg}$ concentrations in moss (2010) at the landscape level as determined by use of the Ecological Land Classification of Europe $\mathrm{ELCE}_{40}$

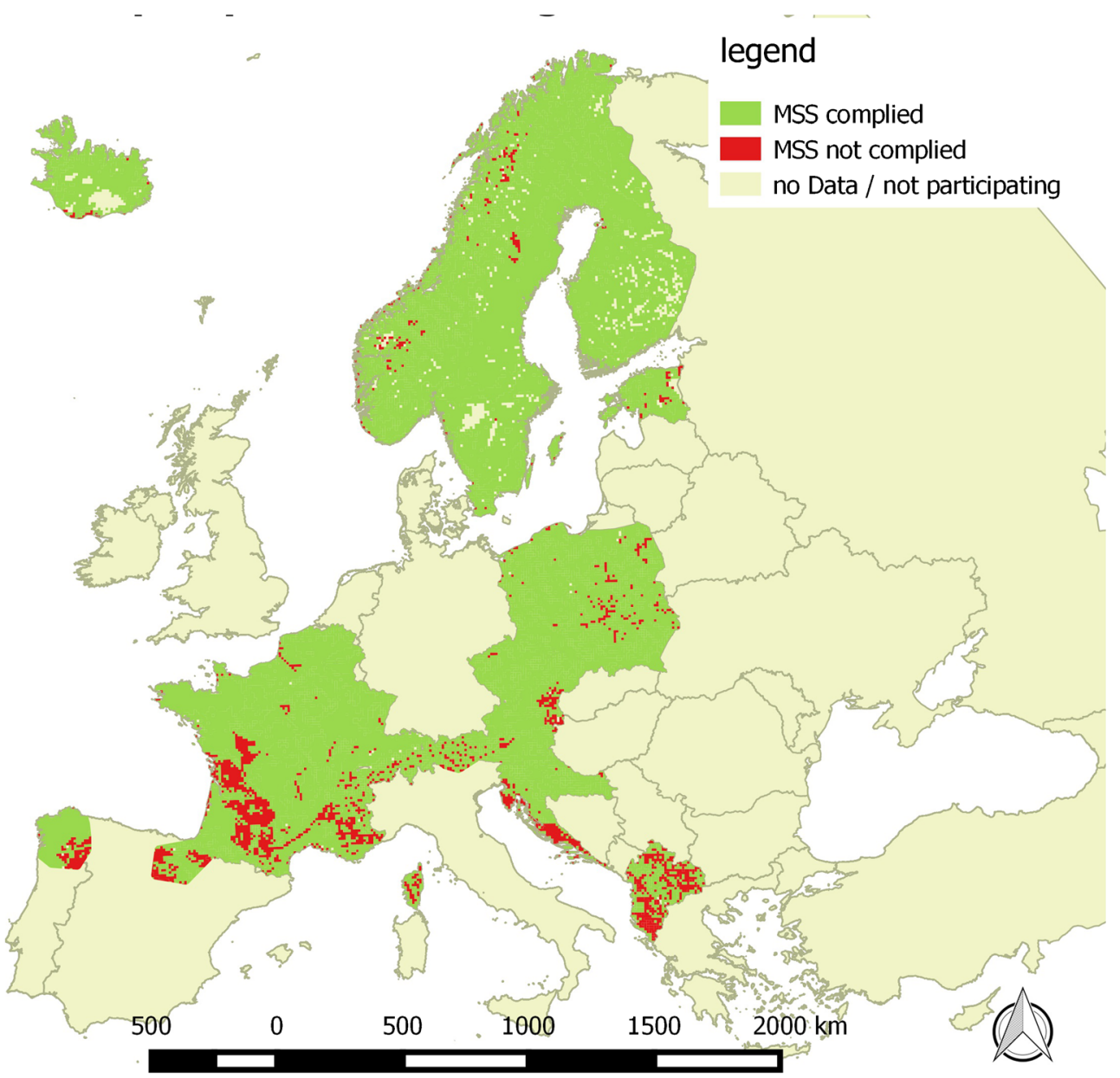

semi-variograms can be found in Figs. S12-S15. With the exception of $\mathrm{Pb}$, low values of $\mathrm{ME}$ indicate low overestimations and underestimations in the variogram models. MPE are the lowest for N (14\%). For selected $\mathrm{HM}(\mathrm{Cd}, \mathrm{Hg}$ and $\mathrm{Pb}), \mathrm{MPE}$ ranges between $20.1 \%$ and $28.1 \%$. Figures $5,6,7$ and 8 are based on equal interval classification and thus do not rely on toxicological assessments.

For $\mathrm{Cd}$, the mean of geostatistically estimated concentration in moss is $0.18 \mathrm{mg} \mathrm{kg}^{-1}$. The mean of measured values came out to be somewhat higher $\left(0.21 \mathrm{mg} \mathrm{kg}^{-1}\right)$. Areas with $\mathrm{Cd}$ concentrations nearby or below this Europe-wide mean are located in Scandinavia, Northern Spain, France, Switzerland, Austria, Czech Republic and parts of Southeast Europe (Fig. 5). The highest $\mathrm{Cd}$ concentrations (above $0.8 \mathrm{mg} \mathrm{kg}^{-1}$ ) were observed in Poland and Slovakia.

The geostatistical surface estimation of $\mathrm{Pb}$ concentration in moss is $3.42 \mathrm{mg} \mathrm{kg}^{-1}$ in comparison to $3.98 \mathrm{mg} \mathrm{kg}^{-1}$ as the mean of the measured values. In 2010, most of the European countries revealed low $\mathrm{Pb}$ concentrations in moss below $5 \mathrm{mg} \mathrm{kg}^{-1}$ (Fig. 6). Based on the geostatistical surface estimations, the highest $\mathrm{Pb}$ concentrations $\left(>15 \mathrm{mg} \mathrm{kg}^{-1}\right)$ were found in South Poland and some regions of Bulgaria.
The Europe-wide mean of $\mathrm{Hg}$ concentrations in moss for both geostatistically estimated and observed values amount to $0.06 \mathrm{mg} \mathrm{kg}^{-1}$. Below-average $\mathrm{Hg}$ concentrations have been determined for parts of Scandinavia, Estonia, Northern Spain, France, Switzerland, Austria, Czech Republic, Slovenia, Croatia and Kosovo (Fig. 7). Core areas with high Hg concentrations above $0.10 \mathrm{mg} \mathrm{kg}^{-1}$ were detected in Southern Europe and in parts of Norway, Poland and France.

For N, mean of geostatistically estimated concentrations in moss $(=1.28$ mass $\%)$ and observed concentrations $(=1.27$ mass $\%)$ were similar. Main countries with low accumulation of $\mathrm{N}$ in moss (below the mean) are Finland and Estonia (Fig. 8). The generally highest $\mathrm{N}$ concentrations in moss with predominantly $>2$ mass \% were calculated for France, Poland, Czech Republic, Slovakia, the north-east of Croatia and North Bulgaria.

\subsection{Correlation analyses}

In this article, the presentation of results from correlation analyses is mainly focused on $\mathrm{Cd}$ and $\mathrm{Pb}$. The investigation whether element concentrations in moss indicate canopy drip effects additionally includes $\mathrm{Hg}$ and $\mathrm{N}$. 
Fig. 4 Compliance of minimum sample size for $\mathrm{N}$ concentrations in moss (2010) at the landscape level as determined by use of the Ecological Land Classification of Europe $\mathrm{ELCE}_{40}$

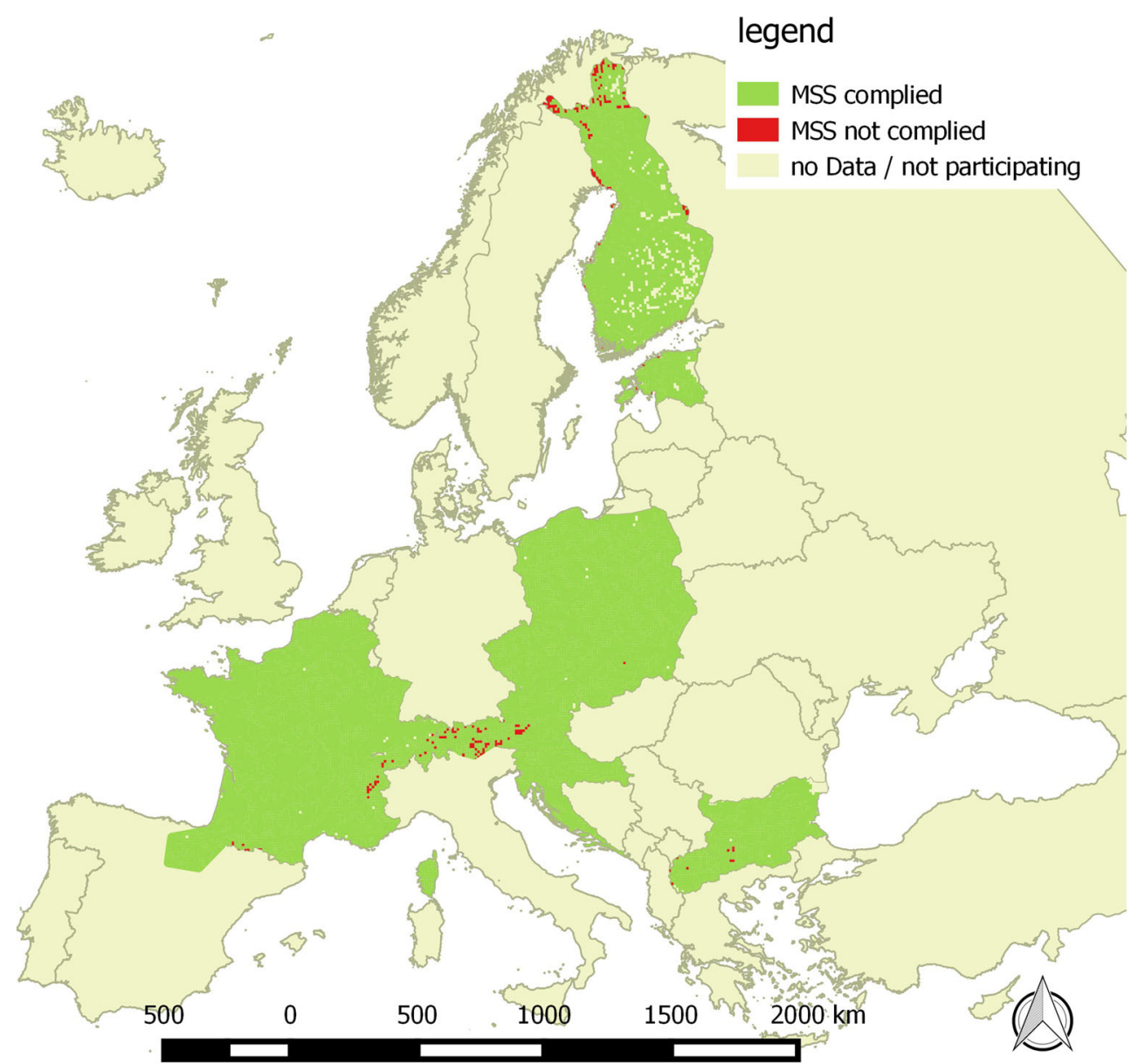

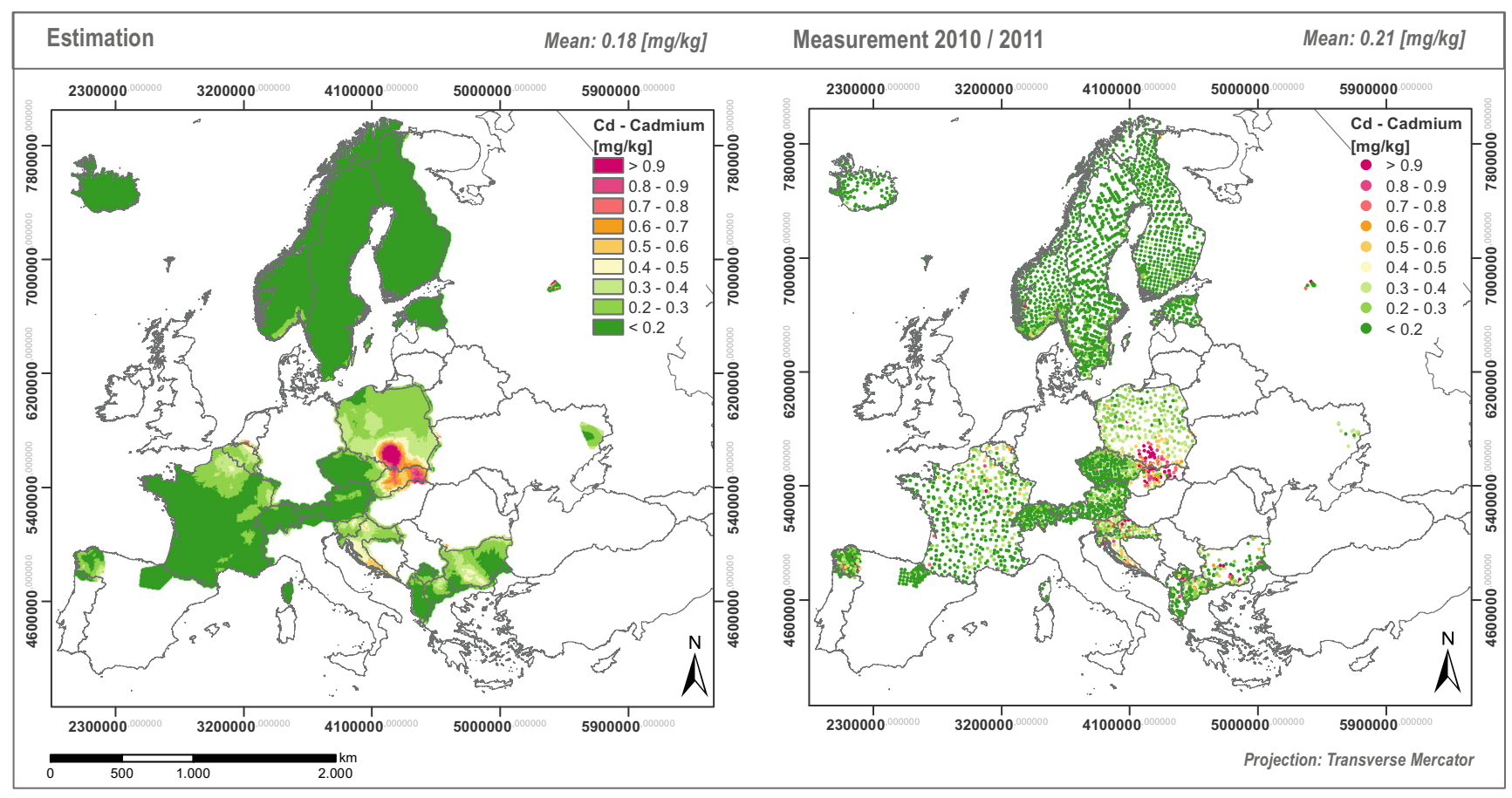

Fig. 5 Geostatistical surface estimations (left) and measured values (right) of Cd concentrations in moss (2010) 


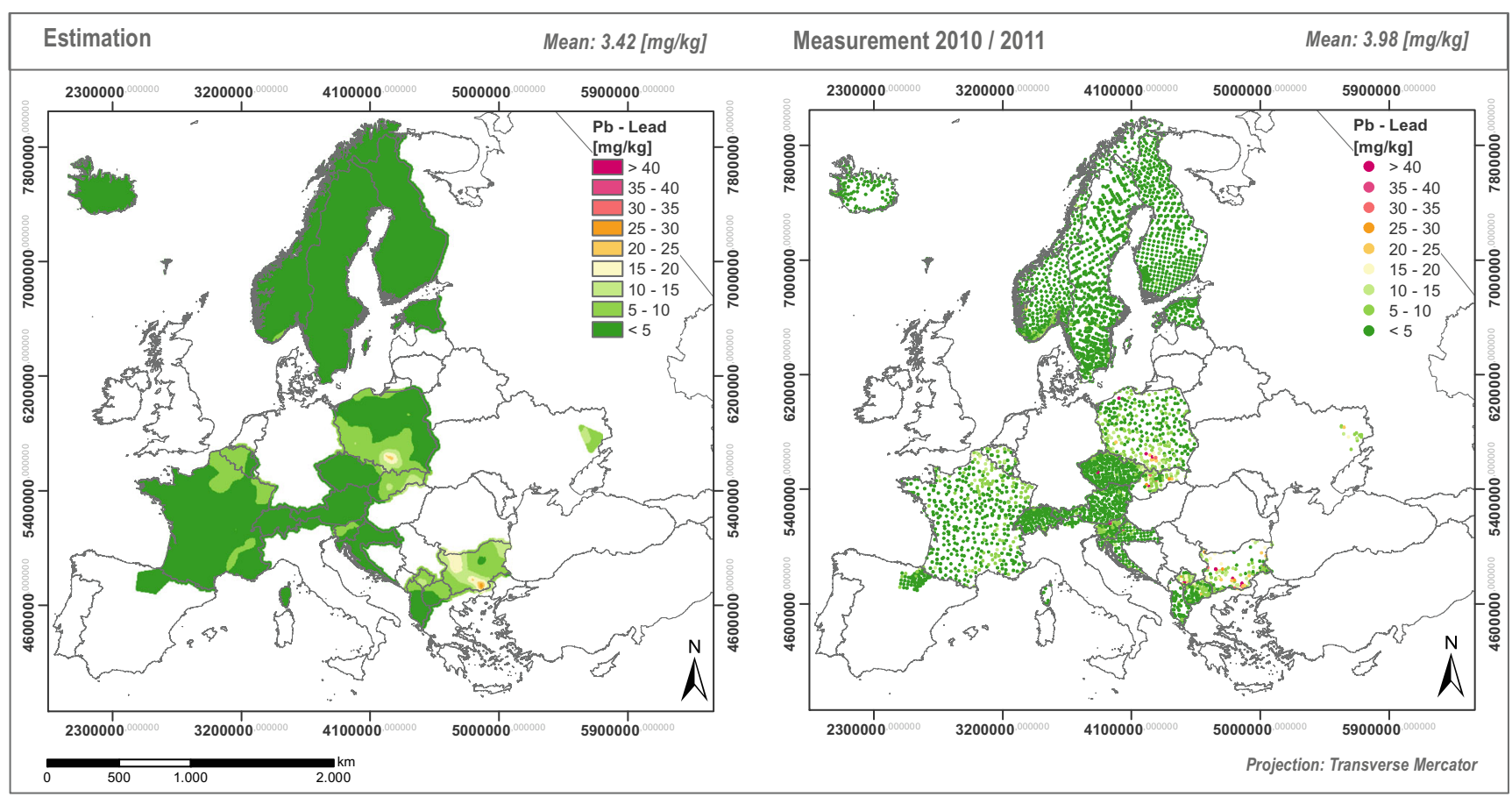

Fig. 6 Geostatistical surface estimations (left) and measured values (right) of Pb concentrations in moss (2010)

\subsection{Correlation between EMEP and LE modelled HM deposition values}

The LE median of total Cd deposition (2007-2011, $25.70 \mathrm{\mu g} \mathrm{m}^{-2}$ year $^{-1}$ ) is by $28 \%$ lower than the median value calculated for Germany using the EMEP model (2007-2011, $35.59 \mu \mathrm{g} \mathrm{m}^{-2}$ year $^{-1}$ ). This difference is, according to the
Wilcoxon test, statistically significant $(p<0.05)$. Similar clear differences become evident when comparing the maximum values. The coefficients of variation of the LE results are much lower than those calculated from the EMEP modelling results. The correlations between EMEP and LE total Cd deposition amount to $r_{\mathrm{S}}=0.47$ (2007-2011) and $r_{\mathrm{S}}=0.39$ (2005) (Nickel and Schröder 2016).

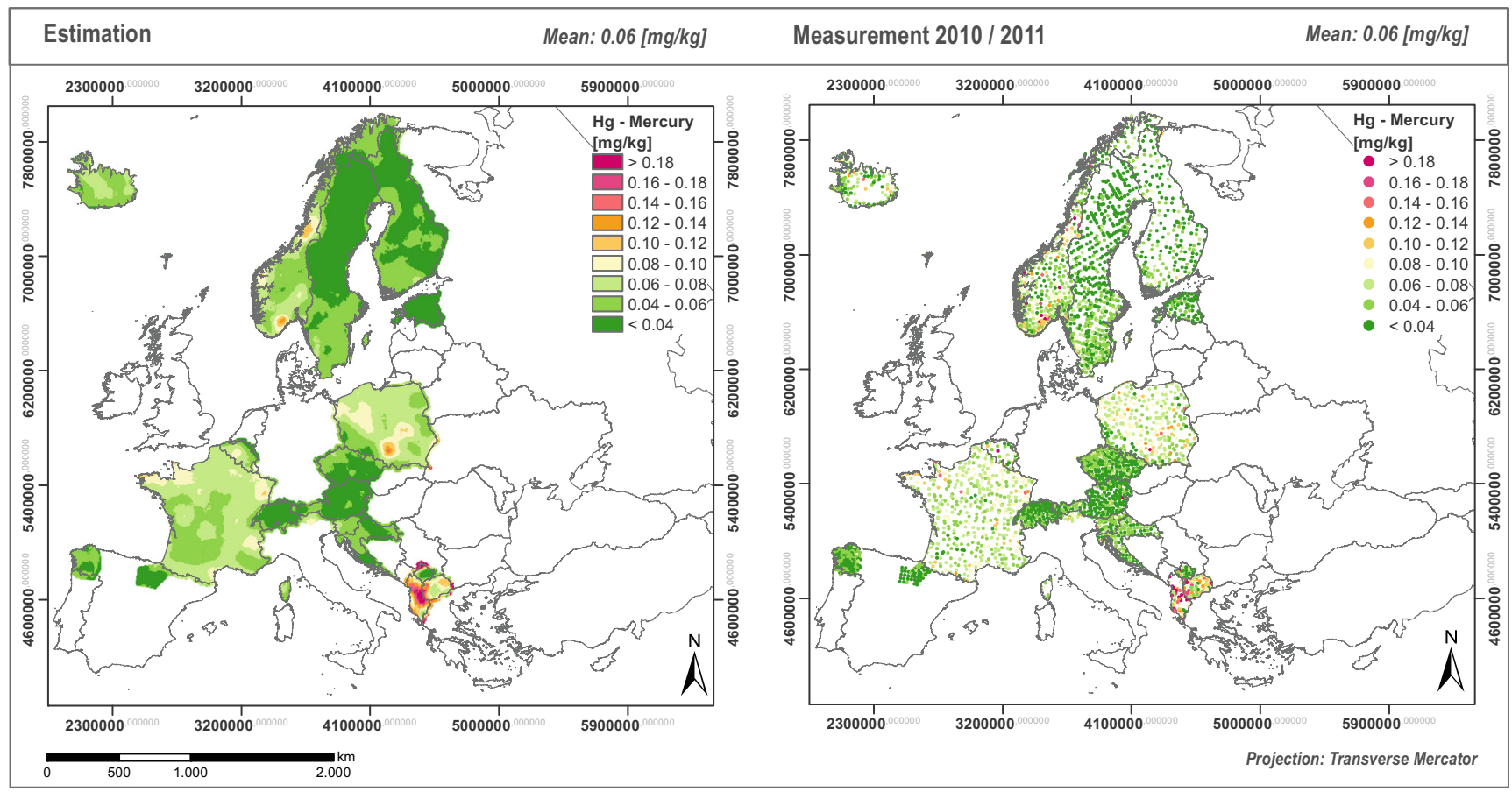

Fig. 7 Geostatistical surface estimations (left) and measured values (right) of $\mathrm{Hg}$ concentrations in moss (2010) 




Fig. 8 Geostatistical surface estimations (left) and measured values (right) of N concentrations in moss (2010)

Comparing the spatial distributions of total atmospheric $\mathrm{Cd}$ deposition modelled by EMEP and LE indicates that the differences between the results are strongly correlated with the amount of EMEP values $\left(r_{\mathrm{S}}>0.9\right)$. In the south of Bavaria, LE deposition values exceed those modelled by EMEP $(\mathrm{Cd}, 45 \%$ higher). The most distinct differences between EMEP and LE results were calculated for coniferous forests, followed by those for deciduous forests and grassland. This is reflected by the spatial patterns detailed by Nickel and Schröder (2016). The coefficients quantifying the correlation between EMEP and LE values are for coniferous forests $r_{\mathrm{S}}=0.7$, for deciduous forests $r_{\mathrm{S}}=0.44$ and for grassland $r_{\mathrm{S}}=0.22$. Thus, the spatial $\mathrm{Cd}$ deposition patterns mapped from the EMEP and LE data are most similar for coniferous forests. The median value of $\mathrm{Cd}$ deposition modelled for forests exceeds that for grassland by factor 3.2 (EMEP) and 1.4 (LE), respectively. The latter value corresponds to measurements of $\mathrm{Cd}$ concentrations in moss sampled beneath canopies and beyond forests conducted during 2012 and 2013 (Meyer et al. 2015c).

EMEP and $\mathrm{LE}$ results for $\mathrm{Pb}$ deposition are correlated with $r_{\mathrm{S}}=0.56$ (2007-2011) and $r_{\mathrm{S}}=0.35$ (2005). The differences between EMEP and LE results are at maximum where EMEP values are particularly high. The LE values exceed the EMEP calculations in the south of Bavaria ( $\mathrm{Pb}, 12 \%$ higher). As proven for $\mathrm{Cd}$, the modelled (EMEP and $\mathrm{LE}$ ) $\mathrm{Pb}$ deposition for coniferous forests is higher than that for deciduous forests and grassland. This fact is supported by the spatial patterns (Nickel and Schröder 2016). The differences between EMEP and $\mathrm{LE}$ are much more pronounced for $\mathrm{Pb}$ than for $\mathrm{Cd}$. Regions with higher EMEP deposition values for grassland are located in north-western Germany. LE values exceeding EMEP values for grassland were identified in southern Germany. For forests, EMEP calculated values are much higher than those derived by LE, especially in northern Germany. Correlations between EMEP and LE amount for coniferous forests by $r_{\mathrm{S}}=0.54$, for deciduous forests by $r_{\mathrm{S}}=0.37$ and grassland by $r_{\mathrm{S}}=0.26$. Thus, the spatial patterns mapped from the EMEP and LE data are most similar for coniferous forests. The median $\mathrm{Pb}$ deposition for forests as calculated by LE exceeds the LE grassland deposition value by factor 1.4, which is clearly lower than that derived from EMEP modelling (2.9). According to Meyer et al. (2015c), Pb concentrations in moss sampled in 2012-2013 beneath canopies exceeded those sampled beyond canopies by factor 1.9 .

\subsection{Correlation between EMEP and LE modelled HM deposition values and respective HM concentrations measured in moss in $\mathbf{2 0 0 5}$ and spatially estimated for unsampled locations}

The correlation between the moss concentration and modelled Cd deposition was $r_{\mathrm{S}}=0.31(L E)$ and $r_{\mathrm{S}}=0.27$ (EMEP) $(p<0.01)$ for Germany and $0.66(L E)$ and $r_{\mathrm{S}}=0.59$ $(E M E P)(p<0.01)$ for Europe. The difference between both coefficients is significant. Land cover-specific deposition and moss concentrations are correlated with $r_{\mathrm{S}}=0.60$ (grassland/ LE, $p<0.01$ ), $r_{\mathrm{S}}=0.35$ (coniferous forests/LE, $p<0.01$ ), $r_{\mathrm{S}}=0.44$ (coniferous forests/EMEP, $p<0.01$ ) and $r_{\mathrm{S}}=0.34$ (grassland/EMEP, $p<0.01$ ). Thus, when specifying land cover in Germany, the correlation between $\mathrm{Cd}$ concentration 
measured in moss and deposition is more pronounced. When distinguishing between regions above and below the median, $\mathrm{Cd}$ deposition and concentration in moss reveal higher correlations compared to the whole territory of Germany.

The correlation between $\mathrm{Pb}$ concentrations in moss and deposition values in Germany was $r_{\mathrm{S}}=0.35$ (LE) and $r_{\mathrm{S}}=0.27$ (EMEP). For Europe, the concentration of $\mathrm{Pb}$ in moss is strongly correlated with modelled deposition (EMEP $\left.r_{\mathrm{S}}=0.65, \mathrm{LE} r_{\mathrm{S}}=0.56, p<0.01\right)$. Regarding different land cover, the correlation coefficients range between $r_{\mathrm{S}}=0.44$ (LE, $p<0.01$ ) and $r_{\mathrm{S}}=0.41$ (EMEP, $p<0.01$ ) for coniferous forests and $r_{\mathrm{S}}=0.12$ (LE, $p<0.05$ ) and $r_{\mathrm{S}}=0.42$ (EMEP, $p<0.05$ ) for deciduous forests. Thus, considering land cover data partly enables detecting enhanced correlations.

The statistical relations between geostatistical surface estimations of $\mathrm{Cd}$ and $\mathrm{Pb}$ concentrations in moss specimens sampled across Germany and Europe and corresponding deposition values (EMEP, LE) are shown in Fig. 9. Thereby, regions with values below and above respective medians are regarded.

The correlations between LE deposition of $\mathrm{Cd}$ and moss estimations amount to $r_{\mathrm{S}}=0.37$ (Germany, $p<0.01$ ) and $r_{\mathrm{S}}=0.81$ (Europe, $p<0.01$ ). The relations between EMEP deposition values and moss concentrations are $r_{\mathrm{S}}=0.70$ (Europe, $p<0.01$ ) and $r_{\mathrm{S}}=0.43$ (Germany, $p<0.01$ ). Below the median, the correlation between moss data and LE values is more distinct while above the median the opposite holds true. The differences between all coefficients compared are statistically significant.

The relations between estimated $\mathrm{Pb}$ concentrations in moss and modelled deposition were computed with $r_{\mathrm{S}}=0.49$ (LE) and $r_{\mathrm{S}}=0.44$ (EMEP) for Germany with $r_{\mathrm{S}}=0.42$ (LE) and $r_{\mathrm{S}}=0.57$ (EMEP) and Europe. For both $\mathrm{Cd}$ and $\mathrm{Pb}$ could be found that the correlation between deposition and moss concentration considerably decreases in cases where the ratio between EMEP/LE deposition data exceeded 6-8. This suggests that the uncertainty of deposition modelling is reflected not only by the ratio between both models but also by differences of spatial patterns of deposition and moss values.

\subsection{Correlation between EMEP and LE modelled HM deposition values and respective $\mathrm{HM}$ concentrations in tree foliage and surface soil specimens}

Correlations were interpreted for tree foliar specimens (ESB) with more than 10 samplings. The number of samplings between 2005 and 2011 amounted to 28 (beech), 17 (poplar), 34 (spruce) and 6 (pine). Metal-specific correlations were determined and compiled in Fig. 10.

For $\mathrm{Cd}$, measured $\mathrm{Cd}$ concentration in leaves and LE modelled deposition reveal significant positive correlations $(p<0.05)$. For LE, Kendall's correlation coefficients amount to $r_{\tau}=0.29$ (beech) and $r_{\tau}=0.36$ (poplar). By contrast, correlations based on EMEP data are non-significant and somewhat lower than LE $\left(r_{\tau}=0.23\right.$ for beech and $r_{\tau}=0.26$ for poplar $)$. Correlations between $\mathrm{Cd}$ concentration in 1-year-old shoots from spruce and modelled deposition were ecosystem type-specific. For LE, significant strong and moderate correlations $(p<0.05)$ were found for 1-year-old shoots from spruce in forest ecosystems $\left(r_{\tau}=0.64\right)$ and near natural terrestrial ecosystems $\left(r_{\tau}=0.49\right)$. Again, EMEP data showed non-significant and lower correlations compared to LE ( $r_{\tau}=0.40$ in forestry ecosystems and $r_{\tau}=0.36$ in near natural terrestrial ecosystems). For spruce in urban-industrial ecosystems, we found non-significant correlations of $r_{\tau}=0.33$ (LE) and $r_{\tau}=0.29$ (EMEP). Agricultural ecosystems for both LE and EMEP revealed negative and pine non-significant correlations due to small sample sizes.

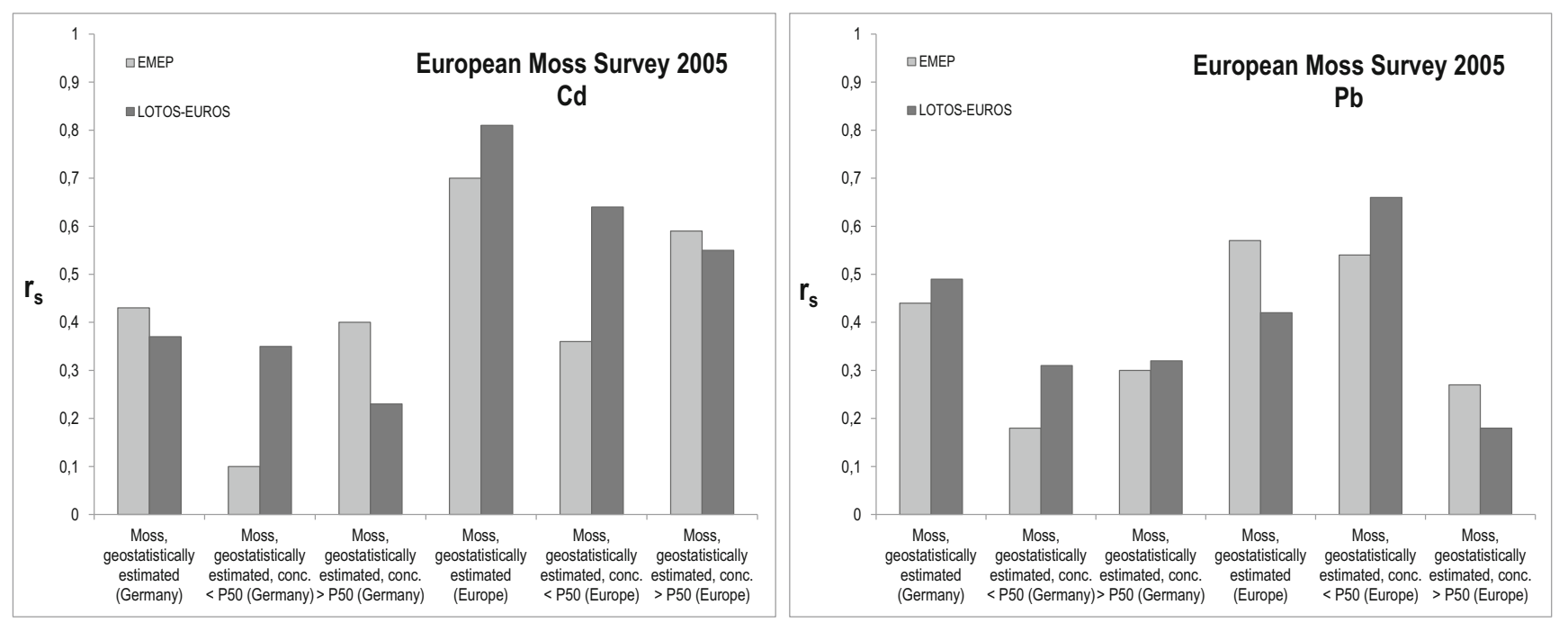

Fig. 9 Coefficients (Spearman) of correlation between geostatistical surface estimations of $\mathrm{Cd}$ and $\mathrm{Pb}$ concentrations in moss and modelled $\mathrm{Cd}$ and $\mathrm{Pb}$ total deposition in Germany and Europe 


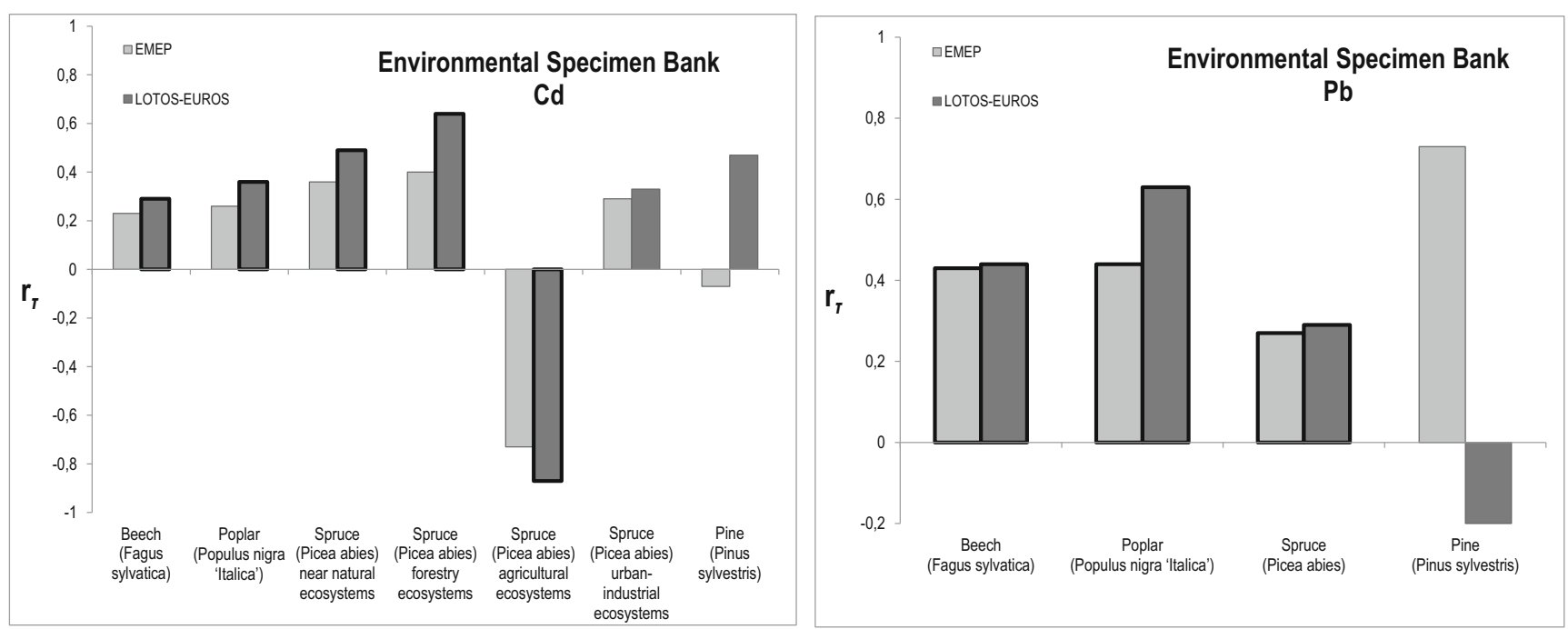

Fig. 10 Coefficients (Kendall) of correlation between $\mathrm{Cd}$ and $\mathrm{Pb}$ concentrations in leaves and needles (ESB) and respective deposition values (LE, EMEP) (Germany, 2007-2011)

For $\mathrm{Pb}$, significant moderate and very strong relationships between measured $\mathrm{Pb}$ concentration in leaves and deposition (LE) were found $(p<0.01)$. Coefficients amount to $r_{\tau}=0.44$ (beech) and $r_{\tau}=0.63$ (poplar). The association between $\mathrm{Pb}$ concentrations in atmospheric deposition (LE) and in 1-yearold shoots from spruce also revealed a moderate coefficient $\left(r_{\tau}=0.47, p<0.01\right)$. Again, the correlation between EMEP deposition values and $\mathrm{Pb}$ concentration in beech foliage is relatively low compared to LE, but appeared to be significant $\left(r_{\tau}=0.43, p<0.01\right)$. Same holds true for poplar $\left(r_{\tau}=0.44\right.$, $p<0.05)$ and 1 -year-old shoots from spruce $\left(r_{\tau}=0.27\right.$, $p<0.05)$. Again, pine was not significantly correlated due to small sample size. Most of the correlations between deposition modelled by LE and moss values are higher than those between EMEP calculations and moss concentrations. However, these differences are not statistically significant.
Coefficients of correlation between concentrations in leaves (ICP Forests Level II) and needles and atmospheric deposition show element- and specimen-specific and, regarding needles, age class-specific variation (Fig. 11).

The highest coefficients could be determined for the correlation between $\mathrm{Cd}$ concentrations in needles of $P$. sylvestris and deposition (LE, $r_{\tau}=0.34, p<0.01$ ) and between respective concentrations for spruce $\left(r_{\tau}=0.28, p<0.01\right)$ and beech $\left(r_{\tau}=0.21, p<0.05\right)$ on the one hand and EMEP deposition values on the other hand. For $\mathrm{Pb}$, the correlations are specific for specimen and age classes of needles. For spruce, pine and beech the correlations were proven to be weak but significant. The highest correlations were found for 2-year-old spruce needles (LE: $r_{\tau}=0.58$; EMEP: $r_{\tau}=0.44$, differences not significant). The respective values for pine are $r_{\tau}=0.47$ 0.58 (LE, 2-year-old needles) and $r_{\tau}=0.20$ EMEP, 1-year-
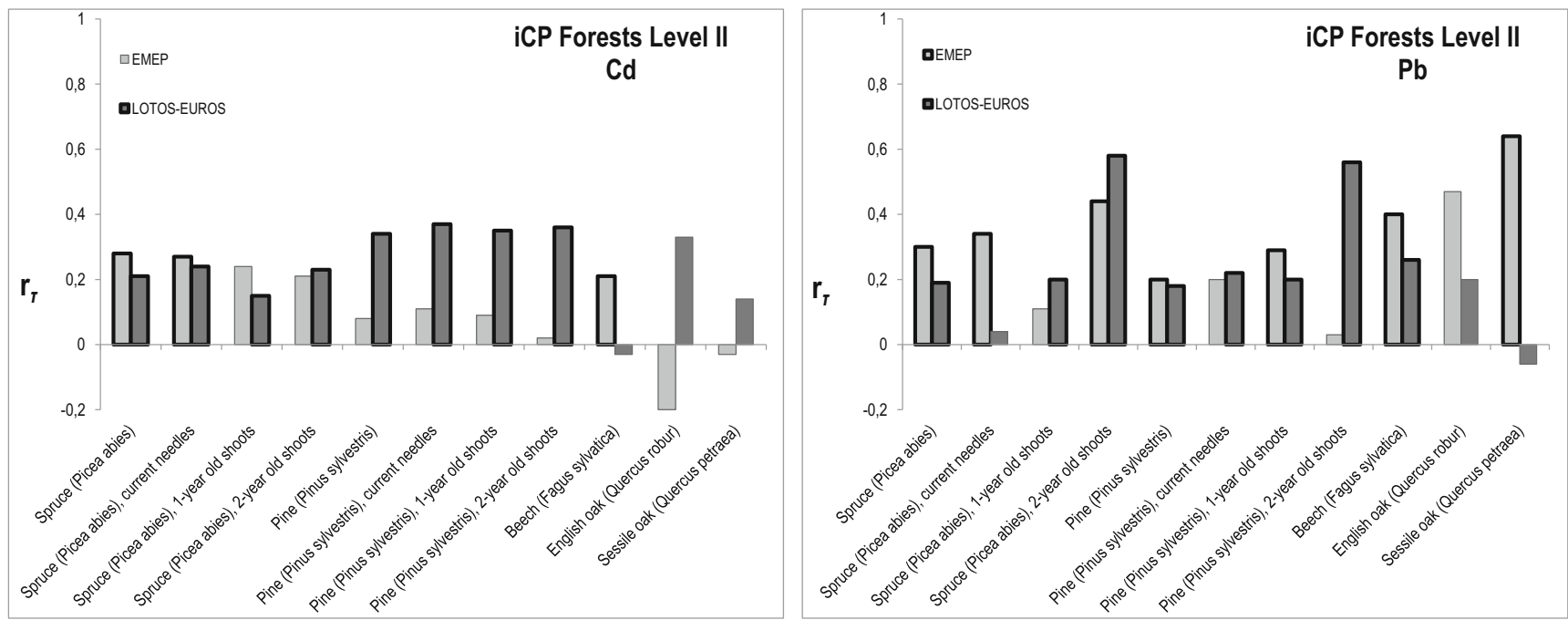

Fig. 11 Coefficients (Kendall) of correlation between concentrations of $\mathrm{Cd}$ and $\mathrm{Pb}$ in leaves and needles (ICP Forests Level II) and respective atmospheric total deposition (LE, EMEP, Germany, 2007-2011) 
old needles). For Quercus robur L. and F. sylvatica L., the coefficients amount to $r_{\tau}=0.40-0.64$ (EMEP).

The coefficients of correlation between $\mathrm{Cd}$ and $\mathrm{Pb}$ concentrations in organic surface layers of soil collected on ICP Forests Level II plots and modelled atmospheric deposition indicate weak layer-specific correlations (Fig. 12, Nickel and Schröder 2016). The highest values were computed for correlations between $\mathrm{Cd}$ concentration in $\mathrm{Oh}$ horizons and deposition with $r_{\tau}=0.31$ (LE, $p<0.01$ ) and $r_{\tau}=0.27$ (EMEP, $p<0.01)$. The difference between these two values is not significant. Regarding $\mathrm{Pb}$ concentrations in soils and deposition, the strongest correlations were determined for $\mathrm{L}$ horizons $\left(r_{\tau}=0.24-0.38\right)$ and Oh horizons $\left(r_{\tau}=0.23-0.32\right)$. Thereby, correlations between soil and deposition modelled with LE are higher than between HM concentrations in soil and deposition calculated with EMEP, but this difference is not statistically significant.

\subsection{Canopy drip effect and other influencing factors}

Bivariate correlation analyses show that the $\mathrm{N}$ concentration in moss collected in north-western Germany is significantly and strongly correlated with atmospheric $\mathrm{N}$ deposition modelled by EMEP $\left(r_{\mathrm{S}} 1, p<0.01\right)$ which was significantly and strongly correlated with the site category $\left(r_{\mathrm{S}}>0.995\right)$. Significant strong correlations exist between the $\mathrm{N}$ concentrations in moss and the distance between sampling sites from the nearest tree crown: $r_{\mathrm{S}}=-0.86$ with $p<0.01$ in 2012 and $r_{\mathrm{S}}=-0.80$ with $p<0.01$ in 2013. These findings were corroborated by multivariate analyses with CART and $\mathrm{rF}$. The CART model with the deposition as top predictor explained 91\% (2012) and 95\% (2013) of the variance. The respective model with the site category as the strongest predictor explained $74 \%$ and $79 \%$ of the variance. The $\mathrm{rF}$ model with the deposition as strongest and the site category as second strongest predictor explained 77\% (2012) and 78\% (2013). Moderate positive correlations (for 2012 and $2013 r_{\mathrm{S}}$ between 0.40 and 0.54 with $p<0.05$ ) were found between the $\mathrm{N}$ concentration in moss sampled at open sites and average mean precipitation, roads and percentage of agricultural land use within a radius of $10 \mathrm{~km}$ around the sampling sites. Complementarily, significant negative correlations exist for the percentage of urban land use (75 and $100 \mathrm{~km}$ radius, $r_{\mathrm{S}}$ between -0.45 and -0.59 with $p<0.05$ in 2012 and $p<0.01$ in 2013) and silvicultural land use (75 and $100 \mathrm{~km}$ radius, $\left.r_{\mathrm{S}}=-0.46, p<0.05\right)$. $\mathrm{N}$ concentrations in moss sampled at sites between open land and forests were found to correlate significantly with the percentage of agricultural land use (50 and $75 \mathrm{~km}$ radius, $r_{\mathrm{S}}$ between $0.54(p<0.05)$ and 0.46 $(p<0.01))$, respectively, and complementarily with the percentage of forests $\left(50,75\right.$ and $100 \mathrm{~km}$ radius, $r_{\mathrm{S}}$ between -0.45 and $-0.57, p<0.05)$ and urban land use $(100 \mathrm{~km}$ radius, $r_{\mathrm{S}}=-0.53$ with $\left.p<0.01\right)$. N concentrations were correlated with the distance of sampling locations to roads $\left(r_{\mathrm{S}}=0.52\right.$ with $p<0.01)$ and average annual precipitation $\left(r_{\mathrm{S}}=0.43\right.$, $p<0.05)$. At throughfall sites, the $\mathrm{N}$ concentrations correlate with the distance of sampling sites to roads $\left(r_{\mathrm{S}}\right.$ between 0.36 and $0.42, p<0.05$ ), percentage of agricultural land use $\left(10 \mathrm{~km}, r_{\mathrm{S}}=0.36 ; 25 \mathrm{~km}, r_{\mathrm{S}}=0.40\right.$; and $50 \mathrm{~km}, r_{\mathrm{S}}=0.43$, $p<0.05)$, average annual precipitation, $\left(r_{\mathrm{S}}=0.51\right.$ and 0.55 , $p<0.05$ and $p<0.01)$, urban land use $\left(1 \mathrm{~km}, r_{\mathrm{S}}=-0.39 ; 5 \mathrm{~km}\right.$, $r_{\mathrm{S}}=-0.42 ; p<0.05 ; 75 \mathrm{~km}, r_{\mathrm{S}}=-0.52,100 \mathrm{~km}, r_{\mathrm{S}}=-0.46$; $p<0.01)$, percentage of silvicultural land use $(75$ and $100 \mathrm{~km}$, $r_{\mathrm{S}}$ between -0.38 and $-0.52, p<0.05$ and $\left.p<0.01\right)$ and distance to the sea $\left(r_{\mathrm{S}}=-0.50, p<0.01\right)$.

These findings based on bivariate correlation analyses could be corroborated by multivariate analyses with CART and $\mathrm{rF}$ yielding a cross-validated ranking of predictors for $\mathrm{N}$

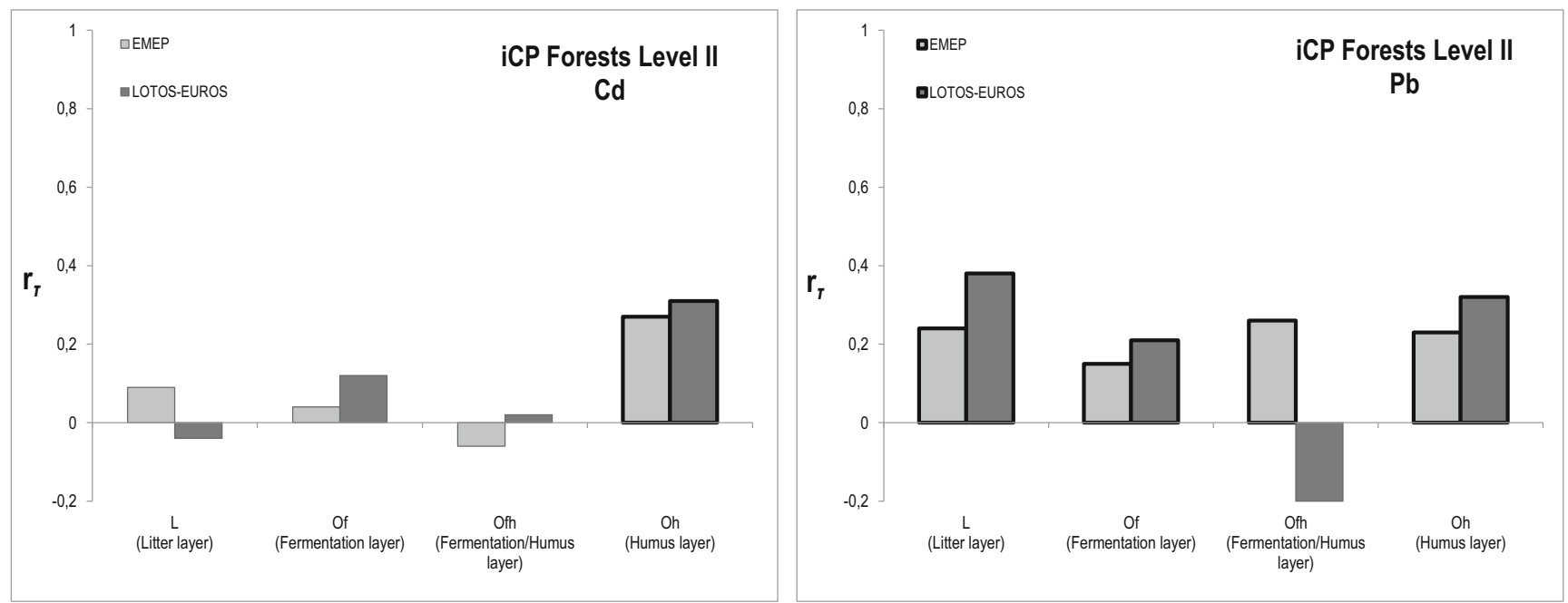

Fig. 12 Coefficients (Kendall) of correlation between concentrations of $\mathrm{Cd}$ and $\mathrm{Pb}$ in organic surface soil layers (ICP Forests Level II) and respective atmospheric total deposition (LE, EMEP, Germany, 2007-2011) 
concentrations in moss. The models identified the atmospheric deposition and the site category as the most powerful predictors and reached to explain 74-95\% of the variance (cf. above).

Similar findings could be confirmed for $\mathrm{Cd}, \mathrm{Hg}$ and $\mathrm{Pb} . \mathrm{Cd}$ concentrations in moss collected in north-western Germany correlate moderately with the site category $\left(r_{\mathrm{S}}=-0.50\right.$ with $p<0.01$ in 2012, $r_{\mathrm{S}}=-0.53$ with $p<0.01$ in 2013). The respective values for $\mathrm{Hg}$ are $r_{\mathrm{S}}=-0.69$ with $p<0.01$ in 2012 and $r_{\mathrm{S}}=-0.71$ with $p<0.01$ in 2013 and for $\mathrm{Pb}$ $r_{\mathrm{S}}=-0.32$ with $p<0.01$ in 2012 and $r_{\mathrm{S}}=-0.53$ with $p<0.01$ in 2013. Cd concentrations in moss sampled at open sites correlated with the percentage of urban land use $(1 \mathrm{~km}$ radius, $\left.r_{\mathrm{S}}=0.50, p<0.01\right)$ and silvicultural land use $(10 \mathrm{~km}$ radius, $r_{\mathrm{S}}=-0.57$, with $\left.p<0.01 ; 5 \mathrm{~km}, r_{\mathrm{S}}=-0.46, p<0.05\right)$. $\mathrm{Hg}$ concentrations collected at open sites were statistically associated with percentages of urban land use $(10 \mathrm{~km}$ radius, $2012, r_{\mathrm{S}}=-0.46 ; 2013, r_{\mathrm{P}}=-0.40, p<0.05 ; 50 \mathrm{~km}$ radius, 2013, $\left.r_{\mathrm{P}}=-0.39, p<0.05\right)$, distance to roads $\left(r_{\mathrm{P}}=0.51\right.$, $p<0.01)$ and agricultural land use $(100 \mathrm{~km}$ radius, $\left.r_{\mathrm{P}}=0.43, p<0.05\right)$. Hg concentrations in moss collected at edge sites were correlated with the distance to roads $\left(r_{\mathrm{P}}=0.43\right.$, $p<0.05$ ), percentage of silvicultural land use ( $1 \mathrm{~km}$ radius, $\left.r_{\mathrm{P}}=0.48, p<0.05\right)$, distance to agricultural land use $\left(r_{\mathrm{P}}=0.47, p<0.05\right)$ and buildings for livestock $\left(r_{\mathrm{P}}=0.45\right.$, $p<0.05)$. Hg concentrations at throughfall sites were found to be correlated with average annual precipitation (2012, $r_{\mathrm{P}}=0.38$ with $p<0.05 ; 2013, r_{\mathrm{P}}=0.64$ with $p<0.01$ ), distance to settlements $\left(r_{\mathrm{P}}=0.50, p<0.01\right)$, technical $\mathrm{Hg}$ emission sources according to E-PRTR $\left(r_{\mathrm{P}}=0.49, p<0.01\right)$, percentage of forest coverage $\left(5 \mathrm{~km}, r_{\mathrm{P}}=0.39, p<0.05\right.$; $\left.75 \mathrm{~km}, r_{\mathrm{P}}=-0.40, p<0.05 ; 100 \mathrm{~km}, r_{\mathrm{P}}=-0.52, p<0.01\right)$. High positive values may be due to local or regional enhanced emissions, correlated interception of forest canopies and windward effects. Negative correlations may be due to lower emission, a reduced interception at forest edges and lee side effects (Holy et al. 2009; Schröder et al. 2008; Mohr et al. 2011).The multivariate analyses confirmed the site category to be the most important predictor for the concentrations of $\mathrm{Cd}$ and $\mathrm{Hg}$ in moss. The respective CART models explained at maximum $46 \%(\mathrm{Cd} \mathrm{2012)}$ and 61\% ( $\mathrm{Hg} \mathrm{2013)}$ of the variance exceeding the respective values derived with $\mathrm{rF}$. The latter holds true for $\mathrm{Pb}$ concentrations in moss, which are, according to a CART model explaining $40 \%$ of the variance, mostly influenced by the percentage of agricultural land $(100 \mathrm{~km}$ radius) as the most powerful predictor, followed by the site category, (Meyer 2017).

\section{Discussion}

This investigation corroborated and complemented currently published results on statistically significant correlations between concentrations of $\mathrm{Cd}, \mathrm{Pb}$ and $\mathrm{N}$ in biomonitors (moss, leaves, needles and soil) and in atmospheric deposition modelled by EMEP and LOTOS-EUROS, which in the following are discussed with regard to some specific methodological aspects and in a broader context.

The modelled deposition data comprise uncertainties of data collected from emission inventories as well as from monitoring and modelling (Schröder et al. 2014). The uncertainty of emission data is difficult to quantify since several national emission inventories do not provide respective information. The uncertainty of modelling results includes intrinsic model uncertainties, the overall model uncertainty and the comparison of modelled values with field observations. To assure the quality of monitoring data, measurements are validated through a quality assurance/quality control process involving the individual institutions responsible for the different sites documented by the reports available in the Chemical Coordinating Centre EMEP series (www.emep.int). In addition to applied reference methods and standard operation procedures, EMEP conducts laboratory and field intercomparison of most components defined by the monitoring programme. Field inter-comparisons are an important part of the quality assurance programme in EMEP to document the overall uncertainty in the methods used (Tørseth et al. 2012). The uncertainty of monitoring data includes the estimation of the uncertainty caused by analytical methods. While laboratory comparisons provide estimations of the accuracy of analytical methods, overall measurement accuracy was estimated by field campaigns. Thus, the results of the study may be confined by some drawbacks resulting from restricted availability of information and resulting uncertainty. For instance, an inter-comparison of the two deposition models (EMEP and LE) should be based on identical emission and meteorological data and the respective result should be referred to an identical spatial and temporal framework (Gusev 2015; Ilyin and Travnikov 2005; Simpson et al. 2014; Ryaboshapko et al. 2007; Schutgens et al. 2016; Zhang et al. 2014). This paper only contains modelled deposition data, so no clear conclusion can be drawn whether moss data complement technical deposition measurements. However, the modelled data were validated against measured data. Pesch et al. (2007) have shown that moss data also correlate with measured deposition data. Nevertheless, moss surveys yield indirect measures of atmospheric deposition which need to be calibrated against measured deposition data. Variations between element concentrations do not only exist in moss samples collected at the same location but also between technical samplers. Additionally, as is true for technical samplers and deposition modelling, the moss technique reveals element-specific differences (e.g. $\mathrm{Pb}$ and $\mathrm{Cd}$ vs. $\mathrm{Hg}$ and $\mathrm{Zn}$ ) and is not able to differentiate high $\mathrm{N}$ deposition due to saturation of $\mathrm{N}$ concentrations in mosses above a certain deposition level (Harmens et al. 2011, 2014). Therefore, element concentrations in moss are timeintegrated surrogates of atmospheric deposition (Harmens et al. 2015a) and might be used complementarily with direct measurements and modelling results to enhance the spatial resolution of 
deposition data needed for the ecosystem-specific assessment of the exposure of terrestrial ecosystems and providing an indication of areas at risk from high atmospheric deposition.

Mosses have been sampled within forests and at selected ICP Forests sites, but not all sites where mosses are collected are influenced by canopy drip. Therefore, canopy drip effects were investigated and the results allowed for calculating canopy drip-influenced values in open field values and vice versa (Meyer 2017). Canopy drip is a site characteristic belonging to the reality of forest ecology. For estimating atmospheric deposition we have to quantify the ratio between deposition values inside and outside of forests. Data to calculate these ratios should be collected in compliance with MSS and geostatistical criteria such as spatial auto-correlation which in general should be implemented in environmental monitoring schemes (Clarke et al. 2010; Cools and de Vos 2011; Ferretti 2010, 2011; Ferretti et al. 2014, Fischer et al. 2014).

According to Lindenmayer and Likens (2011), direct measurements assume that the "right" entities to measure have been selected, that they are well understood in terms of key ecological processes and that they can be measured reliably. Direct measurements abstract from complex phenomena and environmental interrelationships due to practical considerations. Indicator approaches are similar to the direct measurements, but additionally presume surrogacy relationships between an indicator system (organism, population, ecosystem, landscape) and the indicandum for which it is used as a proxy and which could be measured in terms of statistical correlation (Gao et al. 2015; Lindenmayer et al. 2015). Within these constraints, the degree of contamination of an ecosystem may be assessed by determining element concentrations in air, water, soil or sediments in the system. Additionally, many monitoring programmes use monitoring organisms. The most important advantages in determining metal concentrations in biomonitoring organisms rather than in the abiotic environment are the following (Bjerregaard et al. 2015): (1) The organisms concentrate chemicals to measurable concentrations. (2) The organisms reflect the average degree of pollution over time. (3) The concentration in the organisms reflects the bioavailable fraction of the polluting metal, or, in other words, the fraction that is available for uptake by organisms. Additionally, comparing the indication of atmospheric deposition by use of moss with technical facilities, moss surveys yield by far a higher spatial resolution and cover a broader element spectrum. Nevertheless, as is true for all terrestrial monitoring, moss surveys cannot reach a complete coverage of ecosystems but rely on spatial discrete sampling (Ferretti and Fischer 2013). Since environmental assessments, planning and protection need spatially high resolved data, statistics are used to investigate whether the sample point data allow for spatial generalization in terms of calculating mean values for spatial units such as a continent, a country, ecoregions or single sites and calculating surface maps derived from measured values. The computations of the MMS needed indicate that the compliance achieved for Europe and single countries is lower when statistics are conducted at the landscape level (Schröder et al. 2016). This suggests that MSS is dependent on the spatial extent and aim of a study. Hence, the MSS calculated for an area of larger extent might be not valid if one would like to determine concentrations in mosses reliably at the landscape or even at the site level, as for example protected habitats or sites. The investigation could also show that the moss technique is able to reliably detect spatial variances of $\mathrm{HM}$ and $\mathrm{N}$ measurements inside and outside of forests at the site level, confirming findings presented by Gandois et al. (2014) and Skudnik et al. (2014, 2015). From the results shown can be concluded that the requirement for MSS is very much dependent on the aim and spatial resolution of a study and the questions under research.

Geostatistics enabled to map spatial patterns from measurements, i.e. to fill up the space between the measurement sites by spatial estimation. Thus, for the correlation analyses not only the moss measurement values were used but also surface estimations derived from them by kriging. The correlations indicated that the organisms used fairly well indicate atmospheric deposition and, therefore, should be used to enhance the spatial resolution of deposition maps and, subsequently, HM and N critical loads (ARGE StickstoffBW 2014; de Vries and Groenenberg 2009; Giordani et al. 2014; Lorenz et al. 2008; Lorenz and Granke 2009; Reinds and de Vries 2010; Waldner et al. 2015). The latter are, among others, required for assessing and mapping ecosystem conditions. ${ }^{2}$

The results of the investigations presented in this article document that the combination of biomonitoring and deposition modelling enables spatially dense information on $\mathrm{Hg}$ deposition. This helps specifying the exposure of ecosystems across spatial scales and enabling spatially differentiated exposure assessments of ecosystems. This is needed even if environmental and health impacts of $\mathrm{Hg}$ are only indirectly related to ambient atmospheric concentrations of $\mathrm{Hg}$. Toxic effects result from the net conversion of $\mathrm{Hg}$ into bioaccumulating $\mathrm{Hg}$ species occurring under reducing conditions in wetlands and sediments in watersheds and coastal zones, and in the upper ocean. Thus, impacts of $\mathrm{Hg}$ are related not only to emissions and deposition rates, but also to the potential of ecosystems to methylate and to biomagnify $\mathrm{Hg}$ which has to be described by use of data on ecosystem characteristics (Driscoll et al. 2013; UNEP 2013). Results from the International Cooperative Programme on Integrated Monitoring of Air Pollution Effects on Ecosystems (ICP Integrated Monitoring) corroborate that forest catchments far from emission sources in Northern and Central Europe accumulate atmospheric $\mathrm{Hg}$ deposition. $\mathrm{Hg}$ concentrations in terrestrial wildlife not being part of the aquatic food chain are generally low. However, in most of the lakes and rivers in North America and Scandinavia, methylmercury

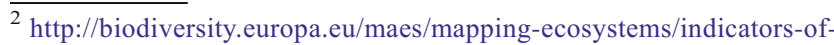
ecosystem-condition
} 
$\left(\mathrm{CH}_{3} \mathrm{Hg}\right)$ is elevated in predatory fish and did not decrease during the past two to three decades (UNECE TF HM, Task Force on Heavy Metals 2006). This Hg long-term data with low spatial resolution should be complemented by the spatially highly differentiated moss data.

Data collected within the ICP Integrated Monitoring indicated that forest catchments far from emission sources of Northern and Central Europe continue to accumulate Cd deposition but soil $\mathrm{Cd}$ concentrations do not exceed thresholds for adverse effects on microbiota or vegetation. Vegetation accumulating $\mathrm{Cd}$ is the primary source of $\mathrm{Cd}$ exposure for terrestrial herbivores but available data indicate that $\mathrm{Cd}$ concentration in terrestrial wildlife do not exceed effect levels. Unlike Hg, Cd does not biomagnify in freshwater ecosystems. There seems to be a low risk of adverse effects due to $\mathrm{Cd}$ exposure of freshwater and marine ecosystems (UNECE TF HM, Task Force on Heavy Metals 2006; UNEP 2010a). However, the evaluation of $\mathrm{Cd}$ emission control policies $\mathrm{Cd}$ must not rely only on pollutant registers, but also on exposure data derived from deposition modelling and biomonitoring as for instance moss surveys.

Concentrations of $\mathrm{Pb}$ measured in forest humus layers investigated within the ICP on Assessment and Monitoring of Air Pollution Effects on Forests (ICP Forests) may exceed thresholds for effects in soil organisms but do not reach concentrations of toxicological significance in terrestrial wildlife. Concentrations of $\mathrm{Pb}$ in freshwater ecosystems influenced by long-range atmospheric transport are relatively low and are not considered a toxicological threat to aquatic organisms. In a significant percentage of European soils, the $\mathrm{Pb}$ concentrations exceed the threshold concentration for adverse effects in soil, and therefore the terrestrial ecosystems are considered to be at risk (UNECE TF HM, Task Force on Heavy Metals 2006). To reliably delineate such regions, exposure data derived by deposition modelling and biomonitoring are needed at high spatial resolution.

Of the other metals regarded in this study $(\mathrm{As}, \mathrm{Cr}, \mathrm{Cu}, \mathrm{Ni}$, $\mathrm{Zn}, \mathrm{Sb}) \mathrm{Cu}$ and $\mathrm{Zn}$ were found to accumulate in forested catchments of Northern and Central Europe. None of these metals reach concentrations due to long-range atmospheric transport and deposition to cause adverse effects on wildlife or human health (UNECE TF HM, Task Force on Heavy Metals 2006). However, long-term deposition modelling and biomonitoring are required as early warning systems enabling to detect changes of emission regimes. Similar to our investigation, Pajak and Jasik (2011) found a clear correlation between the concentration of HM in moss tissue and in organic soil layers. The HM concentrations in mineral soil showed either a not-significant or very weak correlation with the other components of the forest ecosystem. This suggests that mosses and soil organic layer are better biomonitors of heavy metal pollution than mineral soil (Meyer et al. 2014; Nickel et al. 2014, 2015).
$\mathrm{N}$ may affect ecosystems through eutrophication, acidification and direct toxicity, each impacting several ecosystem services (Gaudio et al. 2015; Jones et al. 2014). Based on data collected within the ICP Forests Level II, Ferretti et al. (2014) and Seidling et al. (2014) investigated the relation between forest condition in Europe and potential predictors. For 71 ICP Forests Level II plots, the importance of throughfall $\mathrm{N}$ bulk deposition as predictor for the frequency of trees with defoliation $>25 \%$ was proved for beech and Norway spruce, while the opposite was observed for Scots pine. Higher foliar $\mathrm{N}$ ratios led to higher defoliation $>25 \%$ for all species (Ferretti et al. 2014). Waldner et al. (2014) found that the detection of trends of $\mathrm{N}$ deposition to ICP Forests Level II forest plots was more distinct when using monthly data instead of annual data. The overall decreasing trend for inorganic $\mathrm{N}$ between 1999 and 2010 was about 2\%. Time series of about 10 years were required to detect significant trends in inorganic $\mathrm{N}$ on a single plot. The strongest decrease was observed in western central Europe with high $\mathrm{N}$ deposition whereas stable or slightly increasing deposition during the last 5 years was found east of the Alps and in northern Europe. Waldner et al. (2014) considered further reductions as necessary to reduce $\mathrm{N}$ deposition to levels below which significant harmful effects do not occur in forests according to present knowledge. Such critical loads for organic $\mathrm{N}$ were exceeded on about $30-50 \%$ of 201 ICP Forests Level II forest plots as well as of 43 sites within the Swedish Throughfall Monitoring Network (Waldner et al. 2015). These findings and the results presented in the article at hand suggest complementing forest ecosystem monitoring and assessments by using spatially high resolved long-term moss survey data, for indicating exposure in terms of $\mathrm{HM}$ and $\mathrm{N}$ atmospheric deposition and accumulation.

\section{Conclusion}

Data from moss surveys could be proved to be statistically meaningful in terms of compliance with minimum sample size across several spatial levels computed for both Ecological Land Classes of Europe and for sampling sites in northwestern Germany (objective 1). This is also true in terms of geostatistical criteria such as spatial auto-correlation and, by this, estimated values for unsampled locations and computing surface maps (objective 2). Additionally, the study corroborated that moss indicate atmospheric deposition in a similar way as modelled deposition, tree foliage and natural surface soil at the European and country level, and that they indicate sitespecific variance due to canopy drip (objective 3 ). These results evidenced that moss surveys should complement forest deposition monitoring and impact assessments. Future moss 
monitoring campaigns should include more detailed versions of the Ecological Land Classification and ecosystem typologies based on ecosystem functions (Schröder et al. 2015), e.g. for determining compliance of minimum sample size at the landscape level. Thereby, potential canopy drip effects should be monitored to capture site-specific variances. Further integrative analyses could be tackled for measurements of atmospheric deposition from ICP Forests, element concentrations in moss (e.g. $\mathrm{Al}, \mathrm{Cd}, \mathrm{Cu}, \mathrm{Fe}, \mathrm{Ni}, \mathrm{Zn}$ and $\mathrm{N}$ ) and modelled atmospheric deposition (e.g. $\mathrm{Cd}, \mathrm{Cu}, \mathrm{Ni}, \mathrm{Pb}, \mathrm{Zn}$ and $\mathrm{N}$ ). This would help to stronger link the exposure monitoring by use of moss with effect-related monitoring of forest ecosystem condition (Saarikoski et al. 2015). That approach should be added by physiological investigations on how moss species adjust their cell morphology and metabolism to environmental stress (Basile et al. 2013; Müller et al. 2015; Parrotta et al. 2015). A spatial re-arrangement of EMS sampling sites should be discussed and an adapted sampling size should be investigated by error maps for pollutants which have toxicological and ecological effects. Approval procedures for build stock breeding emitting $\mathrm{N}$ or for $\mathrm{HM}$ emitting plants, it is necessary to have information about background levels, which should be collected by biomonitoring methods such as the moss technique. It is also important that European countries like Germany, Italy, Spain, Ireland, Great Britain and the Netherlands participate continuously in the EMS.

Acknowledgements This research paper was only possible through the help and support of the national authorities of the countries participating in the European Moss Survey 2005 and 2010, of the Federal Environmental Agency, Dessau, Germany, of the Meteorological Synthesizing Centre - East (MSC-E), Moscow, Russia, and of the ICP Vegetation Programme Coordination Centre, Centre for Ecology \& Hydrology, Bangor, UK.

\section{Compliance with ethical standards}

Funding The sampling and chemical analyses were funded by the national authorities of the countries participating in the European Moss Survey 2010. The Federal Environment Agency of Germany funded the statistical investigations on which the presented results were based. Collation and quality control of the EMS data was conducted by the ICP Vegetation Programme Coordination Centre, funded by Defra (UK), UNECE and NERC (UK).

\section{References}

ARGE StickstoffBW (Ministerium für Umwelt, Klima und Energiewirtschaft Baden-Württemberg, Ministerium für Ländlichen Raum und Verbraucherschutz Baden-Württemberg, Ministerium für Verkehr und Infrastruktur Baden-Württemberg) (2014) Ermittlung standortspezifischer Critical Loads für Stickstoff - Dokumentation der Critical Limits und sonstiger Annahmen zur Berechnung der Critical Loads für bundesdeutsche FFH-Gebiete. Karlsruhe:1-187
Basile A, Sorbo S, Conte B, Cardi M, Esposito S (2013) Ultrastructural changes and heat shock proteins 70 induction upon urban pollution are similar to the effects observed under in vitro heavy metals stress in Conocephalum conicum (Marchantiales - Bryophyta). Environ Pollut 182:209-216

Berg B, Dise N (2004) Calculating the long-term stable nitrogen sink in northern European forests. Acta Oecol 26(1):15-21

Bjerregaard P, Andersen CBI, Andersen O (2015) Ecotoxicology of metals - sources, transport, and effects on the ecosystem. In: Nordberg GF, Fowler BA, Nordberg M (eds) Handbook on the toxicology of metals, 4th edn. Vol. 1. Elsevier Science, Amsterdam, pp 425-459

Bleeker A, Draaijers G, van der Veen D, Erisman JW, Möls H, Fonteijn P, Geusebroek M (2003) Field intercomparison of throughfall measurements performed within the framework of the pan European intensive monitoring program of EU/ICP Forest. Environ Pollut 125:123-138. doi:10.1016/S0269-7491(03)00142-8

Breiman L (2001) Random forests. Mach Learn 45:5-32

Breiman L, Friedman J, Olshen R, Stone C (1984) Classification and regression trees. Wadsworth, Belmont, $\mathrm{CA}$

Builtjes P, Schaap M, Wichink Kruit R, Nagel HD, Nickel S, Schröder W (2014) Impacts of heavy metal emissions on air quality and ecosystems in Germany. 1st Progress Report on behalf of the German Federal Environmental Agency, Dessau. April 2014

Clarke N, Zlindra D, Ulrich E, Mosello R, Derome J, Derome K, König N, Lövblad G, Draaijers GPJ, Hansen K, Thimonier A, Waldner P (2010) Sampling and analysis of deposition. Part XIV. In: ICP Forests. Manual on methods and criteria for harmonized sampling, assessment, monitoring and analysis of the effects of air pollution on forests. UNECE, ICP Forests, Hamburg, Germany, pp 66. [ISBN: 978-3-926301-03-1] [online] URL: http://www.icp-forests.org/pdf/ FINAL Depo.pdf

Clarke N, Fischer R, de Vries W, Lundin L, Papale D, Vesala T, Merilä P, Matteucci G, Mirtl M, Simpson D, Paoletti E (2011) Availability, accessibility, quality and comparability of monitoring data for European forests for use in air pollution and climate change science. iForest 4:162-166

Cools N, De Vos B (2011) Availability and evaluation of European forest soil monitoring data in the study on the effects of air pollution on forests. iForest 4:205-211 [online 2011-11-03] URL:http://www. sisef.it/iforest/show.php?id=588

de Vries W, Groenenberg JE (2009) Evaluation of approaches to calculate critical metal loads for forest ecosystems. Environ Pollut 157:34223432

de Vries W, Dobbertin MH, Solberg S, van Dobben HF, Schaub M (2014) Impacts of acid deposition, ozone exposure and weather conditions on forest ecosystems in Europe: an overview. Plant Soil 380:1-45

Dore AJ, Carslaw DC, Braban C, Cain M, Chemel C, Conolly C, Derwent RG, Griffiths SJ, Hall J, Hayman G, Lawrence S, Metcalfe SE, Redington A, Simpson D, Sutton MA, Sutton P, Tang YS, Vieno M, Werner M, Whyatt JD (2015) Evaluation of the performance of different atmospheric chemical transport models and inter-comparison of nitrogen and sulphur deposition estimates for the UK. Atmos Environ 119:131-143

Driscoll CT, Mason RP, Chan HM, Jacob DJ, Pirrone N (2013) Mercury as a global pollutant: sources, pathways, and effects. Environ Sci Technol 2013:4967-4983

Erisman JW, Mols H, Fonteijn P, Geusebroek M, Draaijers G, Bleeker A, van der Veen D (2003) Field intercomparison of precipitation measurements performed within the framework of the Pan European Intensive Monitoring Program of EU/ICP Forests. Environ Pollut 125:139-155. doi:10.1016/S0269-7491(03)00082-4

Fernández JA, Boquete MT, Carballeira A, Aboal JR (2015a) A critical review of protocols for moss biomonitoring of atmospheric deposition: sampling and sample preparation. Sci Tot Environ 517:132150 
Fernández JA, Boquete MT, Carballeira A, Aboal JR (2015b) Response to the comments on A critical review of protocols for moss biomonitoring of atmospheric deposition: Sampling and sample preparation by Fernández JA, Boquete MT, Carballeira A, Aboal JR. Sci Tot Environ 517:132-150. Sci Tor Environ 538:1027-1028

Ferretti M (2010) Harmonizing forest inventories and forest condition monitoring - the rise or the fall of harmonized forest condition monitoring in Europe? iForest 3:1-4 [online: 2010-01-22] URL: http:// www.sisef.it/iforest/show.php?id=518

Ferretti M (2011) Quality assurance: a vital need in ecological monitoring. CAB Rev Perspect Agric Vet Res Nutr Nat Resour 6:1-14

Ferretti M, Fischer RF (eds) (2013) Methods for terrestrial investigations in Europe with an overview of North America and Asia. Developments in environmental science 12: Forest Monitoring, 1st Edition edn. Elsevier Publishers

Ferretti M, Calderisi M, Marchetto A, Waldner P, Thimonier A, Jonard M, Cools N, Rautio P, Clarke N, Hansen K, Merilä P, Potočić N (2014) Variables related to nitrogen deposition improve defoliation models for European forests. Ann Forest Sci. doi:10.1007/s13595-0140445-6

Fischer R, Aas W, De Vries W, Clarke N, Cudlin P, Leaver D, Lundin L, Matteucci G, Matyssek R, Mikkelsen TN, Mirtl M, Öztürk Y, Papale D, Potocic N, Simpson D, Tuovinen J-P, Vesala T, Wieser G, Paoletti E (2011) Towards a transnational system of supersites for forest monitoring and research in Europe - an overview on present state and future recommendations. iForest 4:167-171 [online 2011-0811] URL: http://www.sisef.it/iforest/show.php?id=584

Fischer R, Scheuschner T, Schlutow A, Granke O, Mues V, Olschofsky K, Nagel H-D (2014) Effects evaluation and risk assessment of air pollutants deposition at European monitoring sites of the ICP forests. In: Steyn DG, Builtjes PJH (eds) Air pollution modelling and its application: XXII. Proceedings of the 32nd NATO/SPS International Technical Meeting on Air Pollution and its Application. Utrecht, The Netherlands, 1-11 May 2012. Dordrecht: Springer Netherlands: 89-93

Gandois L, Agnan Y, Leblond S, Séjalon-Delmas N, Le Roux G, Probst A (2014) Use of geochemical signatures, including rare earth elements, in mosses and lichens to assess spatial integration and the influence of forest environment. Atmos Environ 95:96-104

Gao T, Nielsen AB, Hedblom M (2015) Reviewing the strength of evidence of biodiversity indicators for forest ecosystems in Europe. Ecol Indic 57:420-434

Gaudio N, Belyazid S, Gendre X, Mansat A, Nicolas M, Rizzetto S, Sverdrup H, Probst A (2015) Combined effect of atmospheric nitrogen deposition and climate change on temperate forest soil biogeochemistry: a modelling approach. Ecol Model 306:24-34

Giordani P, Calatayud V, Stofer S, Seidling W, Granke O, Fischer R (2014) Detecting the nitrogen critical loads on European forests by means of epiphytic lichens. A signal-to-noise evaluation. For Ecol Manag 311:29-40

Gusev A (2015) Atmospheric deposition of heavy metals on the Baltic Sea. Baltic Sea Environment Fact Sheet 2015, Published: 27 October 2015. http://helcom.fi/baltic-sea-trends/environment-factsheets/hazardous-substances/atmospheric-deposition-of-heavymetals-on-the-baltic-sea

Harmens H, Norris DA, Cooper DM, Mills G, Steinnes E, Kubin E, Thöni L, Aboal JR, Alber R, Carballeira A, Coşkun M, De Temmerman L, Frolova M, Gonzáles-Miqueo L, Jeran Z, Leblond S, Liiv S, Maňkovská B, Pesch R, Poikolainen J, Rühling Å, Santamaria JM, Simonèiè P, Schröder W, Suchara I, Yurukova L, Zechmeister HG (2011) Nitrogen concentrations in mosses indicate the spatial distribution of atmospheric nitrogen deposition in Europe. Environ Pollut 159:2852-2860

Harmens H, Schnyder E, Thöni L, Cooper DM, Mills G, Leblond S, Mohr K, Poikolainen J, Santamaria J, Skudnik M, Zechmeister HG, Lindroos AJ, Hanus-Illnar A (2014) Relationship between site-specific nitrogen concentrations in mosses and measured wet bulk atmospheric nitrogen deposition across Europe. Environ Pollut 194:50-59

Harmens H, Mills G, Hayes F, Norris D, Sharps K (2015a) Twenty eight years of ICP vegetation. An overview of its activities. Ann Di Bot 5: $31-43$

Harmens H, Norris DA, Sharps K, Mills G, Alber R, Aleksiayenak Y, Blum O, Cucu-Man SM, Dam M, De Temmerman L, Ene A, Fernández JA, Martinez-Abaigar J, Frontasyeva M, Godzik B, Jeran Z, Lazo P, Leblond S, Liiv S, Magnússon SH, Maňkovská B, Pihl Karlsson G, Piispanen J, Poikolainen J, Santamaria JM, Skudnik M, Špirić Z, Stafilov T, Steinnes E, Stihi C, Suchara I, Thöni L, Todoran L, Yurukova L, Zechmeister HG (2015b) Heavy metal and nitrogen concentrations in mosses are declining across Europe whilst some "hotspots" remain in 2010. Environ Pollut 200:93-104

Harmens H, Schröder W, Zechmeister HG, Steinnes E, Frontasyeva M (2015c) Comments on Fernández JA, Boquete MT, Carballeira A, Aboal JR (2015). A critical review of protocols for moss biomonitoring of atmospheric deposition: Sampling and sample preparation. Sci Tot Environ 517:132-150. Sci Tot Environ 538:1024-1026

Hennemuth B, Bender S, Bülow K, Dreier N, Keup-Thiel E, Krüger O, Mudersbach C, Radermacher C, Schoetter R (2013) Statistical methods for the analysis of simulated and observed climate data, applied in projects and institutions dealing with climate change impact and adaptation. CSC Report 13, Climate Service Center, Germany:1-135

Hilbrig L, Wellbrock N, Bielefeldt J (2014) Harmonisierte Bestandesinventur. Zweite Bundesweite Bodenzustandserhebung BZE II, Methode. Eberswalde: Johann Heinrich von ThünenInstitut. Thünen Working Paper 26:1-52

Holy M, Pesch R, Schröder W, Harmens H, Ilyin I, Alber R, Aleksiayenak Y, Blum O, Coşkun M, Dam M, De Temmermann L, Fedorets N, Figueira R, Frolova M, Frontasyeva M, Goltsova N, González ML, Grodzińska K, Jeran Z, Korzekwa S, Krmar M, Kuni E, Kvietkus K, Larsen M, Leblond S, Liiv S, Magnússon S, Maňkovská B, Mocanu R, Piispanen J, Rühling Å, Santamaria JM, Steinnes E, Suchara I, Thöni L, Turcsányi G, Urumov V, Wolterbeek HT, Yurukova L, Zechmeister HG (2009) First thorough identification of factors associated with $\mathrm{Cd}, \mathrm{Hg}$ and $\mathrm{Pb}$ concentrations in mosses sampled in the European surveys 1990, 1995, 2000 and 2005. J Atmos Chem 63:109-124

Hornsmann I, Pesch R, Schmidt G, Schröder W (2008) Calculation of an Ecological Land Classification of Europe (ELCE) and its application for optimising environmental monitoring networks. In: Car A, Griesebner G, Strobl J (eds) Geospatial crossroads @ GI Forum '08. Proceedings of the Geoinformatics Forum Salzburg, Wichmann, Heidelberg, pp 140-151

ICP Vegetation (International Cooperative Programme on Effects of Air Pollution on Natural Vegetation and Crops) (2014) Monitoring of atmospheric deposition of heavy metals, nitrogen and POPs in Europe using bryophytes. Monitoring manual 2015 survey. United Nations Economic Commission for Europe Convention on Long-Range Transboundary Air Pollution. ICP Vegetation Moss Survey Coordination Centre, Dubna, Russian Federation, and Programme Coordination Centre. Bangor, Wales, UK:1-26

Ilyin I, Travnikov, O (2005) Modelling of heavy metal airborne pollution in Europe: evaluation of the model performance. EMEP/MSC-E Technical Report 8/2005. Moskow:1-121

Jones L, Provins A, Holland M, Mills G, Hayes F, Emmett B, Hall J, Sheppard L, Smith R, Sutton M, Hicks K, Ashmore M, HainesYoung R, Harper-Simmonds L (2014) A review and application of the evidence for nitrogen impacts on ecosystem services. Ecosyst Serv 7:76-88 
Lindenmayer D, Likens G (2011) Direct measurement versus surrogate indicator species for evaluating environmental change and biodiversity loss. Ecosyst 14:47-59

Lindenmayer D, Pierson J, Barton P, Beger M, Branquinho C, Calhoun A, Caro T, Greig H, Gross J, Heino J, Hunter M, Lane P, Longo C, Martin K, McDowell WH, Mellin C, Salo H, Tulloch A, Westgate M (2015) A new framework for selecting environmental surrogates. Sci Tot Environ 538:1029-1038

Lorenz M, Granke O (2009) Deposition measurements and critical loads calculations: monitoring data, results and perspective. iForest 2:1114 [online: 2009-01-21] URL: http://www.sisef.it/iforest/show.php? $\mathrm{id}=478$

Lorenz M, Nagel HD, Granke O, Kraft P (2008) Critical loads and their exceedances at intensive forest monitoring sites in Europe. Environ Pollut 155:426-435

Meyer M (2017) Standortspezifisch differenzierte Erfassung atmosphärischer Stickstoff- und Schwermetalleinträge mittels Moosen unter Berücksichtigung des Traufeffektes und ergänzende Untersuchungen zur Beziehung von Stickstoffeinträgen und Begleitvegetation. Diss. Univ. Vechta:1-262 + Suppl.:1-86

Meyer M, Schröder W, Pesch R, Steinnes E, Uggerud HT (2014) Spatial patterns and temporal trends of heavy metal concentrations in moss and surface soil specimens collected in Norway between 1990 and 2010. Environ Sci Eur 26:1-18

Meyer M, Schröder W, Nickel S, Leblond S, Lindroos AJ, Mohr K, Poikolainen J, Santamaria JM, Skudnik M, Thöni L, Beudert B, Dieffenbach-Fries H, Schulte-Bisping H, Zechmeister HG (2015a) Relevance of canopy drip for the accumulation of nitrogen in moss used as biomonitors for atmospheric nitrogen deposition in Europe. Sci Total Environ 538:600-610

Meyer M, Schröder W, Pesch R, Steinnes E, Uggerud HT (2015b) Multivariate association of regional factors with heavy metal concentrations in moss and natural surface soil sampled across Norway between 1990 and 2010. J Soils Sed 15:410-422

Meyer M, Schröder W, Hoffmann A (2015c) Effect of canopy drip on accumulation of nitrogen and heavy metals in moss, Pollution Aatmosphérique, $\mathrm{N}^{\circ} 226$, available at: http://lodel.irevues.inist.fr/ pollution-atmospherique/index.php?id=5159

Michel A, Seidling W (eds) (2015) Forest condition in Europe: 2015 technical report of ICP Forests. Report under the UNECE Convention on Long-Range Transboundary Air Pollution (CLRTAP). Vienna: BFW Austrian Research Centre for Forests. BFWDokumentation 21/2015:1-182

Michel AK, Seidling W, Lorenz M, Becher G (eds) (2014) Forest condition in Europe 2013. Technical report of ICP forests under the UNECE Convention on Long-Range Transboundary Air Pollution (CLRTAP). Johann Heinrich von Thünen-Institut, Eberswalde; Hamburg. Thünen Working Paper 19, $134 \mathrm{p}$

Mohr K, Suda J, Kiehne S, Ahrens F, Landscheidt S, Pünjer L S (2011) Untersuchungen zur Bewertung der Auswirkungen von Ammoniakund Stickstoff-Depositionen auf Pflanzen und Ökosysteme im Nahbereich von Stallanlagen (BESTAND). Abschlussbericht im Auftrag der Bundesanstalt für Landwirtschaft und Ernährung, Bonn, FKZ 2809HS015, $117 \mathrm{~S}$.

Müller SJ, Gütle DD, Jacquot J-P, Reski R (2015) Can mosses serve as model organisms for forest research? Ann Forest Sci DOI. doi:10. 1007/s13595-015-0468-7

Murray T (2005) PBT (persistent, bioaccumulative, and toxic) chemicals. In: Wexler P (ed) Encyclopedia of toxicology, 3rd edn. Academic Press, Oxford, pp 762-764

Nickel S, Schröder W (2016) Integrative evaluation of data derived from biomonitoring and models indicating atmospheric deposition of heavy metals. Environ Sci Pollut Res:1-23. doi:10.1007/s11356015-6006-1 [published online 2016.01.07]

Nickel S, Hertel A, Pesch R, Schröder W, Steinnes E, Uggerud HT (2014) Modelling and mapping spatio-temporal trends of heavy metal accumulation in moss and natural surface soil monitored 19902010 throughout Norway by multivariate generalized linear models and geostatistics. Atmos Environ 99:85-93

Nickel S, Hertel A, Pesch R, Schröder W, Steinnes E, Uggerud HT (2015) Correlating concentrations of heavy metals in atmospheric deposition with respective accumulation in moss and natural surface soil for ecological land classes in Norway between 1990 and 2010. Environ Sci Pollut Res 22(11):8488-8498

Nordberg GF, Nogawa K, Nordberg M (2014) Chapter 32-cadmium. In: Nordberg GF, Fowler BA, Nordberg M (eds) Handbook on the toxicology of metals. $4^{\text {th }}$ edn. Vol 2. Specific Metals. Elsevier Science, Amsterdam, pp 667-716

Olsson U (2005) Confidence intervals for the mean of a log-normal distribution. J Stat Edu 13:1-8

Pajak M, Jasik M (2011) Heavy metal ( $\mathrm{Zn}, \mathrm{Pb}, \mathrm{Cd})$ concentration in soil and moss (Pleurozium schreberii) in the Brynica district, southern Poland. iForest 4:176-180 [online 2011-08-11] URL: http://www. sisef.it/iforest/show.php?id=581

Parrotta L, Guerriero G, Sergeant K, Cai G, Hausman J-F (2015) Target or barrier? The cell wall of early- and later-diverging plants vs cadmium toxicity: differences in the response mechanisms. Front Plant Sci $6: 1-16$

Pesch R, Schröder W, Genssler L, Goeritz A, Holy M, Kleppin, L, Matter Y (2007) Moos-Monitoring 2005 / 2006: Schwermetalle IV und Gesamtstickstoff. Berlin (Umweltforschungsplan des Bundesministers für Umwelt, Naturschutz und Reaktorsicherheit. FuE-Vorhaben 20564 200, Abschlussbericht, im Auftrag des Umweltbundesamtes); 90 S., 11 Tab., 2 Abb. (Texteil); 51 S. + 41 Karten, 34 Tabellen, 46 Diagramme (Anhangsteil)

Prasad AM, Iverson LR, Liaw A (2006) Newer classification and regression tree techniques: bagging and random forests for ecological prediction. Ecosyst 9:181-199

Rautio P, Fürst A, Stefan K, Raitio H, Bartels U, 2010 Sampling and analysis of needles and leaves. Manual on methods and criteria for harmonized sampling, assessment, monitoring and analysis of the effects of air pollution on forests, UNECE, ICP Forests Programme Co-ordinating Centre, Hamburg. Manual Part XII, 19 pp [http:// www.icpforests.org/Manual.htm]

Reinds GJ, de Vries W (2010) Uncertainties in critical loads and target loads of sulphur and nitrogen for European forests: analysis and quantification. Sci Total Environ 408:1960-1970

Rüdel H, Schröder W, von der Trenck KT, Wiesmüller GA (2009) Substance-related environmental monitoring. Work group 'Environmental Monitoring' - position paper. Environ Sci Pollut Res 16(5):486-498

Ryaboshapko A, Russell Bullock Jr O, Christensen J, Cohen M, Dastoor A, Ilyin I, Petersen G, Syrakov D, Artz RS, Davignon D, Draxler RR, Munthe J (2007) Intercomparison study of atmospheric mercury models: 1 . Comparison of models with short-term measurements Sci Tot Environ 376:228-240

Saarikoski H, Barton DN, Mustajoki J, Keune H, Gomez Baggethun E, Langemeyer J (2015) Multi-criteria decision analysis (MCDA) in ecosystem service valuation. In: Potschin M, Jax K (Eds), OpenNESS ecosystem service reference book. EC FP7 Grant Agreement no. 308428. Available via: www.openness-project.eu/ library/reference-book

Sachs L, Hedderich J (2009) Angewandte Statistik. Methodensammlung mit R. Springer-Verlag, Berlin, Heidelberg, pp 1-813

Schröder W, Pesch R (2007) Synthesizing bioaccumulation data from the German metals in mosses surveys and relating them to ecoregions. Sci Total Environ 374:311-327

Schröder W, Hornsmann I, Pesch R, Schmidt G, Markert B, Fränzle S, Wünschmann S, Heidenreich H (2007) Nitrogen and metals in two regions in Central Europe: significant differences in accumulation in mosses due to land use? Environ Monit Assess 133:495-505 
Schröder W, Englert C, Pesch R, Zechmeister HG, Thöni L, Suchara I, Maňkovská B, Jeran Z, Harmens H, Grodzinska K, Alber R (2008) Metallakkumulation in Moosen: Standörtliche und regionale Randbedingungen des Biomonitoring von Luftverunreinigungen. Umweltwiss Schadstoffforsch - Z Umweltchem Ökotox 20:120-132

Schröder W, Pesch R, Schönrock S, Harmens H, Mills G, Fagerli H (2014) Mapping correlations between nitrogen concentrations in atmospheric deposition and mosses for natural landscapes in Europe. Ecol Indic 36:563-571

Schröder W, Nickel S, Jenssen M, Riediger J (2015) Methodology to assess and map the potential development of forest ecosystems exposed to climate change and atmospheric nitrogen deposition: a pilot study in Germany. Sci Total Environ 521-522:108-122

Schröder W, Nickel S, Schönrock S, Meyer M, Wosniok W, Harmens H, Frontasyeva MV, Alber R, Aleksiayenak J, Barandovski L, Danielsson H, de Temmermann L, Fernández Escribano A, Godzik B, Jeran Z, Pihl Karlsson G, Lazo P, Leblond S, Lindroos A-J, Liiv S, Magnússon SH, Mankovska B, Martínez-Abaigar J, Piispanen J, Poikolainen J, Popescu IV, Qarri F, Santamaria JM, Skudnik M, Špirić Z, Stafilov T, Steinnes E, Stihi C, Thöni L, Uggerud HT, Zechmeister HG (2016) Spatially valid data of atmospheric deposition of heavy metals and nitrogen derived by moss surveys for pollution risk assessments of ecosystems. Environ Sci Pollut Res 23:10457-10476

Schutgens NAJ, Gryspeerdt E, Weigum N, Tsyro S, Goto D, Schulz M, Stier P (2016) Will a perfect model agree with perfect observations? The impact of spatial sampling. Atmos Chem Phys Discuss. doi:10. 5194/acp-2015-973 in review

Seidling W, Sanders T, Akselsson C, Cools N, De Marco A, de Vos B, de Vries W, Etzold S, Ferretti M, Fischer U, Giordani P, Graf Pannatier E, Hansen K, Jonard M, Marchetto A, Nevenic R, Rautio P, Reinds G, Skudnik M, Solberg S, Skudnik M, Jeran Z, Batič F, Simončič P, Lojen S, Kastelec D (2014) Influence of canopy drip on the indicative N, S and $\delta 15 \mathrm{~N}$ content in moss Hypnum cupressiforme. Environ Pollut 190:27-35

Simpson D, Andersson C, Christensen JH, Engardt M, Geels C, Nyiri A, Posch M, Soares J, Sofiev M, Wind P, Langner J (2014) Impacts of climate and emission changes on nitrogen deposition in Europe: a multi-model study. Atmos Chem Phys 14:6995-7017

Skudnik M, Jeran Z, Batic F, Simončič P, Lojen S, Kastelec D (2014) Influence of canopy drip in the indicative $\mathrm{N}, \mathrm{S}$ and $\delta 15$ content in moss Hypnum cupressiforme. Environ Pollut 190:27-35

Skudnik M, Jeran Z, Batič F, Simončič P, Kastelec D (2015) Potential environmental factors that influence the nitrogen concentration and $\delta 15 \mathrm{~N}$ values in the moss Hypnum cupressiforme collected inside and outside canopy drip lines. Environ Pollut 198:78-85

Špirić Z, Stafilov T, Vučković I, Glad M (2014) Study of nitrogen pollution in Croatia by moss biomonitoring and Kjeldahl method. J Environ Sci Health, Part A: Toxic / Hazard Subst Environ Eng 49: $1402-1408$

Stankovic S, Kalaba P, Stankovic AR (2014) Biota as toxic metal indicators. Environ Chem Lett 12:63-84

Steinnes E (1989) Cadmium in the terrestrial environment: impact of longrange atmospheric transport. Toxicol Environ Chem 19:139-145

Tchounwou PB, Yedjou CG, Patlolla AK, Sutton DS (2012) Heavy metals toxicity and the environment. Mol Clin Environ Toxicol Exp Suppl 101(2012):133-164 [Author manuscript; available in PMC 2014 August 26]
Tørseth K, Aas W, Breivik K, Fjæraa M, Fiebig M, Hjellbrekke AG, Lund Myhre C, Solberg S, Yttri KE (2012) Introduction to the European Monitoring and Evaluation Programme (EMEP) and observed atmospheric composition change during 1972-2009. Atmos Chem Phys 12:5447-5481

UBA (2008) Umweltprobenbank des Bundes - Konzeption. Available at: http://www.umweltprobenbank.de/upb_static/fck/download/ Konzeption Okt 2008 de.pdf

UNECE TF HM (Task Force on Heavy Metals) (2006) Best available scientific information on the effects of deposition of heavy metals from long-range atmospheric transport. Sufficiency and effectiveness review of the 1998 Protocol on Heavy Metals, UN/ECE Convention on Long-range Transboundary Air Pollution. Geneva: 1-132 [http://www.unece.org/fileadmin/DAM/env/lrtap/TaskForce/ tfhm/effects_of_deposition_of_HMs_final_June_16.pdf]

UNEP (2010a) Final review of scientific information on cadmium. UNEP Chemicals Branch, Geneva, Switzerland, pp 1-118

UNEP (2010b) Final review of scientific information on lead. UNEP Chemicals Branch, Geneva, Switzerland, pp 1-101

UNEP (2013) Global mercury assessment 2013. Sources, emissions, releases and environmental transport. UNEP Chemicals Branch, Geneva, Switzerland, pp 1-32

Verikas A, Gelzins A, Bacauskiene M (2011) Mining data with random forests: a survey and results of new tests. Pattern Recogn 44:330-349

Vučković I, Špirić Z, Stafilov T, Kušan V, Bačeva K (2013) The study on air pollution with nickel and vanadium in Croatia by using moss biomonitoring and ICP-AES. B Environ Contam Tox 91:481-487

Waldner P, Marchetto A, Thimonier A, SchmittM RM, Granke O, Mues V, Hansen K, Pihl Karlsson G, Žlindra D, Clarke N, Verstraeten A, Lazdins A, Schimming C, Iacoban C, Lindroos AJ, Vanguelova E, Benham S, Meesenburg H, Nicolas M, Kowalska A, Apuhtin V, Napa U, Lachmanová Z, Kristoefel F, Bleeker A, Ingerslev M, Vesterdal L, Molina J, Fischer U, Seidling W, Jonard M, O’Dea P, Johnson J, Fischer R, Lorenz M (2014) Detection of temporal trends in atmospheric deposition of inorganic nitrogen and sulphate to forests in Europe. Atmos Environ 95:363-374

Waldner P, Thimonier A, Graf Pannatier E, Etzold S, Schmitt M, Marchetto M, Rautio P, Derome K, Maileena Nieminen T, Nevalainen S, Lindroos A-J, Merilä P, Kindermann G, Neumann M, Cools N, de Vos B, Roskams P, Verstraeten A, Hansen K, Pihl Karlsson G, Dietrich H-P, Raspe S, Fischer R, Lorenz M, Iost S, Granke O, Sanders TGM, Michel A, Nagel H-D, Scheuschner T, Simoncic P, von Wilpert K, Meesenburg H, Fleck S, Benham S, Vanguelova E, Clarke N, Ingerslev M, Vesterdal L, Gundersen P, Stupak I, Jonard M, Potocic N, Minaya M (2015) Exceedance of critical loads and of critical limits impacts tree nutrition across Europe. Ann For Sci 72:929-939

Williams G (2011) Data mining with rattle and R. Springer, The art of excavating data for knowledge discovery $374 \mathrm{pp}$

Zhang K, Wan H, Liu X, Ghan SJ, Kooperman GJ, Ma PL, Rasch PJ, Neubauer D, Lohmann U (2014) Technical note: on the use of nudging for aerosol-climate model intercomparison studies. Atmos Chem Phys 14:8631-8645

Ziegler A, König IR (2014) Mining data with random forests: current options for real-world applications. Wiley Interdisciplinary Reviews: Data Mining and Knowledge Discovery 4:55-63

Žlindra D, Eler K, Clarke N, Simončič P (2011) Towards harmonization of forest deposition collectors - case study of comparing collector designs. iForest 4:218-225. doi:10.3832/ ifor0586-004 